DIW BERLIN

Discussion

Papers

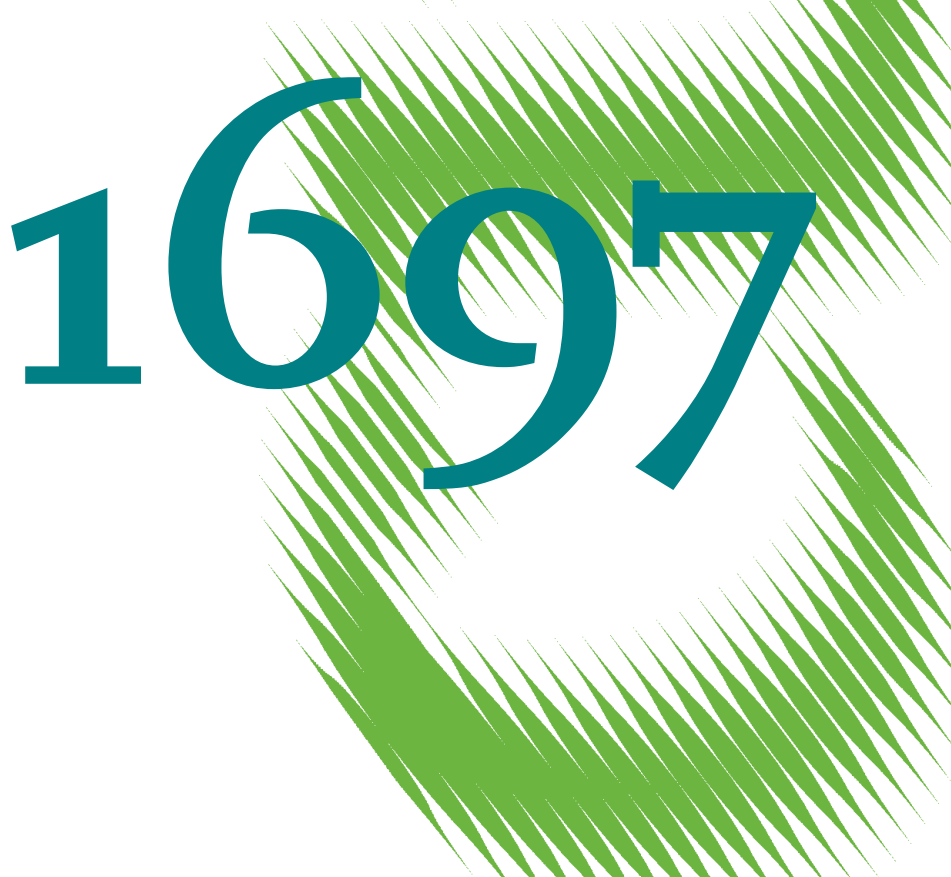

Capital Taxation and Government Debt Policy with Public Discounting 
Opinions expressed in this paper are those of the author(s) and do not necessarily reflect views of the institute.

IMPRESSUM

(C) DIW Berlin, 2017

DIW Berlin

German Institute for Economic Research

Mohrenstr. 58

10117 Berlin

Tel. +49 (30) $89789-0$

Fax +49 (30) $89789-200$

http://www.diw.de

ISSN electronic edition 1619-4535

Papers can be downloaded free of charge from the DIW Berlin website:

http://www.diw.de/discussionpapers

Discussion Papers of DIW Berlin are indexed in RePEc and SSRN:

http://ideas.repec.org/s/diw/diwwpp.html

http://www.ssrn.com/link/DIW-Berlin-German-Inst-Econ-Res.html 


\title{
Capital Taxation and Government Debt Policy with Public Discounting*
}

\author{
Malte Rieth \\ DIW Berlin ${ }^{\dagger}$
}

July 15, 2017

\begin{abstract}
This paper characterizes capital taxation and public debt policy in a quantitative macroeconomic model with an impatient government and uncertainty. The government has access to linear taxes on capital and labor, and to non-state-contingent bonds. Government impatience generates positive and empirically realistic longrun levels of both capital taxes and public debt. Prior predictive analysis shows that the simulated model matches the distribution of both variables in a sample of 42 countries, alongside other statistics. The paper then presents econometric evidence that countries with higher political instability, used as an approximation of unobservable public discount rates, have both higher capital taxes and debt.
\end{abstract}

Keywords: Fiscal policy, prior predictive analysis, political instability, macro panel, Ramsey optimal policy.

JEL classification: E62, H21, H63, C23.

${ }^{*}$ I thank the editor and two anonymous referees for helpul comments and suggestions. I also thank Stefania Albanesi, Fabio Canova, Tom Krebs, Ludger Linnemann, Wolfram Richter, and Andreas Schabert and participants of workshops and seminars at the University of Dortmund, RGS Econ, and Scottish Economic Society Annual Conference and of an internal seminar for comments and discussions. Any remaining errors are mine.

${ }^{\dagger}$ German Institute for Economic Research (DIW Berlin), mrieth@diw.de 


\section{Introduction}

Two prominent results in the theory of optimal fiscal policy are that in the long-run, or on average, (i) capital is not taxed, and (ii) public debt is zero or negative. ${ }^{1}$ Both prescriptions contrast strongly with fiscal policy around the globe. ${ }^{2}$ To bridge this gap, this paper builds a quantitative model of optimizing fiscal policy in which the government discounts the future at higher rates than the private sector. The model matches the distribution of capital taxes and public debt in a sample of 42 countries, alongside other business cycle statistics. Specifically, it rationalizes that capital taxes and debt are positive in mean, and thereby solves two puzzles in the literature simultaneously. The paper then presents econometric evidence consistent with the model's predictions that politically more unstable countries have higher capital taxes and debt.

The model builds on Aiyagari et al. (2002), Kumhof and Yakadina (2007), and Farhi (2010). The first paper analyzes the optimal properties of labor taxation and debt in a representative-agent discrete-time framework with incomplete markets. A fully benevolent government can issue non-state-contingent bonds and has access to linear labor taxes to finance a stochastic stream of wasteful expenditures. When setting its instruments, it takes into account the equilibrium reaction of the private sector and commits to future policy. The authors show that, under certain assumptions, longrun debt is negative. Into this setup, the second paper introduces a government that discounts the future at higher rates than the private sector, as in Arrow and Kurz (1970) and Grossman and Van Huyck (1988), and transactions costs of bond holdings for private agents, following Heaton and Lucas (1996). The combined effect of these two additional features is that long-run government debt is positive. The third study returns to the assumption of a benevolent policy maker with the same time preferences as the private sector but introduces capital and focuses on the optimal behavior of capital taxes. The author shows that they are roughly zero on average and extremely volatile compared to labor taxes, and that government debt contains a unit root component.

In this paper, I introduce government short-sightedness and bond transaction costs into a similar setup as in Farhi (2010) to study the joint behavior of capital taxes and debt under public discounting and uncertainty. As an additional departure from the latter paper, I introduce capital tax adjustment costs which induce smoothing of capital taxes over time. I find that in the long-run capital taxes and public debt are both positive. Intuitively, a government with stronger preferences for nearby consumption

\footnotetext{
${ }^{1}$ For capital taxation see, for example, Judd (1985), Chamley (1986), Chari et al. (1994), Farhi (2010). For government debt see Aiyagari et al. (2002) and Adam (2011). The Chamley-Judd result is criticized on theoretical grounds by Straub and Werning (2014) who show that optimal long-run capital taxes are generally not zero.

${ }^{2}$ See Trabandt and Uhlig (2011) and OECD (2014).
} 
than households sets a positive tax on capital to drive a wedge between the intertemporal rate of substitution and the marginal rate of transformation of consumption to align the latter with its own time preferences. Moreover, it uses debt to shift labor taxes into the future up the point where the associated transaction costs equal the benefits of further debt-financed labor tax cuts.

In the first part of the study, I analyze the quantitative properties of the model economy subject to shocks to government expenditures as well as to permanent and transitory technological progress. Using Bayesian prior predictive analysis, I show that the model replicates the distributions of capital taxes and debt in a sample of 42 (mainly advanced) economies for the period 1985-2014. In particular, it generates positive mean capital taxes and debt and matches the variance of the distribution of mean capital taxes and debt across countries. It also yields standard deviations, autocorrelations, and correlations with government consumption shocks of all fiscal instruments and of consumption that mostly conform with the data. On the other hand, it has difficulty in matching the correlation of taxes with output. I explain these findings by highlighting the relative contribution of the three main features of the model-government impatience, bond transaction costs, and capital tax adjustment costs-to the simulated moments and by studying impulse response functions.

In the second part, I present econometric evidence on the relation between different measures of political instability, taken as approximations of the unobservable discount rates of governments, and capital taxes and debt, respectively. Consistent with the predictions of the model, there is robust evidence of a statistically significant and economically relevant relation: higher political instability is associated with higher capital taxes and government debt. This relation holds across different measures of political instability, when correcting for potentially relevant third variables, as well as when using alternative estimators. Moreover, it holds out-of-sample in the period 1965-1982.

The analysis contributes to a line of research that provides explanations for nonzero capital taxation. Most closely related are two sets of papers that both study the implications of higher public discount rates for capital taxation but differ in the assumption about whether the government can commit to future policies. On the one hand, Arrow and Kurz (1970) consider full commitment. They show that optimal financing of endogenous public investment implies positive taxation of capital. Distinct from the present paper, they assume a constant private savings rate and focus on public investment, which is absent here. Also considering full commitment, Bonis and Spataro (2005) study optimal financing of wasteful exogenous government consumption. They obtain that capital taxes are positive along the path of transition to a steady state but generally not in the steady state. More importantly, however, both aforementioned studies are theoretical explorations based on deterministic continuous-time frameworks, 
whereas this paper focuses on the quantitative and stochastic properties of capital taxation and debt. On the other hand, Aguiar et al. (2009) consider the case of limited commitment and allow for aggregate shocks. They analyze an open economy and show that capital taxes are positive if the government discounts the future at rates higher than the world interest rate. ${ }^{3}$ Reis (2012) considers a closed economy without aggregate risk. Here, interest rates are determined endogenously and the combination of an impatient government and a lack of commitment implies that capital is taxed in the long-run. The present paper deviates from the latter study by assuming full commitment, considering a stochastic environment, and mainly studying the quantitative properties of the model. Finally, there are various alternative theoretical explanations for positive capital taxation put forth in the literature. ${ }^{4}$

The study also relates to a strand of literature that rationalizes positive levels of public debt. Going back to Grossman and Van Huyck (1988), in related studies Persson and Svensson (1989), Alesina and Tabellini (1990), and Amador (2004) develop models of political instability where an incumbent government takes into account that it might loose office and therefore values the future less. Battaglini and Coate (2008) show that pork-spending can also lead to a present bias of the government. Kumhof and Yakadina (2007) assume that the government has a higher discount rate than private agents. All three types of models predict that income taxes and government debt are higher relative to a case where public and private preferences coincide. However, they are silent about capital taxes. On the other hand, Devereux and Wen (1998) show in an endogenous growth model that political instability implies positive levels of both public debt and capital taxes. Different to the analysis here, their model does not contain labor taxes and aggregate economic shocks.

This paper complements the existing studies by presenting a quantitative model featuring an impatient government that matches data on capital taxes and debt, and econometric evidence that policy myopia is an empirically relevant explanation of why governments tax capital and accumulate debt. The intended contribution is thus mainly quantitative and empirical, as the model embeds the theoretical insight going back to Arrow and Kurz (1970) that diverging public and private discount rates can imply positive capital taxes into a quantitative state-of-the art optimal taxation framework following Farhi (2010). Moreover, to my best knowledge, this is the first paper which shows empirically that political instability is a determinant of capital taxes. Finally,

\footnotetext{
${ }^{3}$ The paper also discusses the case of full commitment. Here, however, they find that capital taxes are zero in the long run. This result relies on the infinite elasticity of capital in an open economy.

${ }^{4}$ These are, among others: balanced budget rules combined with logarithmic utility (see Lansing, 1999), Markov-perfect equilibria with lack of commitment (see Martin, 2010), heterogenous private discount rates (see Diamond and Spinnewijna, 2011), and idiosyncratic risk in an OLG model (see Hiraguchi and Shibata, 2015).
} 
the analysis does not rule out other explanations for non-zero capital taxation as the econometric evidence indeed suggests that political instability explains a relevant part but not the full variation in capital taxes.

The paper is structured as follows. The next section lays out the model. Section 3 presents the calibration and Section 4 and 5 contain the results. Sections 6 concludes.

\section{The model}

This section first describes the economy and defines the competitive equilibrium for a given policy. Then, it sets up the policy problem and derives the equilibrium under optimizing fiscal policy. There are three sources of uncertainty: shocks to transitory and permanent productivity and to government expenditures. The shocks materialize at the beginning of each period and are observed by all agents when taking their decisions.

\subsection{Households}

The private sector consists of households and a financial intermediary. Households are identical, infinitely-lived, and of mass one. Following Farhi (2010), they produce output with a constant returns to scale production function $K_{t}+F\left(K_{t}, n_{t}, a_{t}, Z_{t}\right)$, using labor $n_{t}$ and capital $K_{t}$ as inputs. The production function allows for the depreciation of capital with the rate $\delta$. The variable $a_{t}$ is a stationary productivity shock which follows a first-order autoregressive process in logs: $\ln a_{t}=\rho_{a} \ln a_{t-1}+\varepsilon_{t}^{a}$ with i.i.d. innovations $\varepsilon_{t}^{a} \sim \mathcal{N}\left(0, \sigma^{a}\right)$. The shock $Z_{t}$ is non-stationary technological progress. The stochastic growth rate of this variable is $z_{t}=Z_{t} / Z_{t-1}$ and evolves according to $\ln \left(z_{t} / z\right)=\rho_{z} \ln \left(z_{t-1} / z\right)+\varepsilon_{t}^{z}, \quad \varepsilon_{t}^{z} \sim \mathcal{N}\left(0, \sigma^{z}\right)$, where $z \geq 1$ is the deterministic gross growth rate. For future reference, I denote by $x_{t}=X_{t} / Z_{t-1}$ the detrended version of a generic trending variable $X_{t}$.

The objective of a representative household is given by

$$
E_{0} \sum_{t=0}^{\infty} \beta^{t}\left(\frac{c_{t}^{1-\sigma}-1}{1-\sigma}-\frac{\nu n_{t}^{1+\varphi}}{1+\varphi}\right),
$$

where $c_{t}$ denotes consumption and $\beta \epsilon(0,1)$ is the discount factor. To ensure that the growth rate does not affect detrended consumption I will only consider cases of $[\sigma=1, z>1]$ or $[\sigma \neq 1, z=1]$. The household has to pay linear taxes on labor income $\tau_{t}^{n}$, it can invest in non-state-contingent government bonds $b_{t+1}$ at the period $t$ price $1 / R_{t}$, where $R_{t}$ is the gross rate of return, it operates a firm, and supplies labor as well as demands labor $n_{t}^{d}$ at wage $w_{t}$ at a competitive market. For the sake of realism, markets for government bonds are incomplete, following Angeletos (2002) and Aiyagari 
et al. (2002), as most governments issue only limited amounts of state-contingent debt, if at all, probably because the underlying state-dependency is difficult to characterize and verify. Adam and Grill (2013) derive market incompleteness endogenously from contracting frictions. Moreover, the household has to pay flat-rate taxes $\tau_{t}^{k}$ on the base $F\left(k_{t}, n_{t}^{d}, Z_{t}, a_{t}\right)-w_{t} n_{t}^{d}$. This formulation allows for capital depreciation to be deductible, in line with Mendoza et al. (1994). Its budget constraint reads

$c_{t}+\frac{z_{t} b_{t+1}}{R_{t}}+z_{t} k_{t+1}+\theta_{t} \leq\left(1-\tau_{t}^{n}\right) w_{t} n_{t}+\left(1-\tau_{t}^{k}\right)\left[F\left(k_{t}, n_{t}^{d}, Z_{t}, a_{t}\right)-w_{t} n_{t}^{d}\right]+k_{t}+b_{t}+\xi_{t}$,

where $\theta_{t}$ are transaction costs which have to be paid to a financial intermediary when the household enters the bond market, maintaining either a short or a long position. Following Heaton and Lucas (1996), they are quadratic in bond holdings

$$
\theta_{t}=\frac{\tilde{\theta}}{2} b_{t+1}^{2}
$$

The transaction costs can be interpreted either as trading costs or as a wedge between the borrowing and lending rates due to monitoring costs each period which depend on the stock of debt. They imply that, ceteris paribus, an increase in debt leads to an increase in the interest rate on government bonds. Such a relation commands broad empirical support (see Gale and Orszag, 2003, Engen and Hubbard, 2004, Laubach, 2009, Kumar and Baldacci, 2010, Borgy et al., 2011). In the model, they increase the costs of borrowing and thereby prevent the government from reaching its natural debt limit. The assumption of convex portfolio adjustment costs is also commonly used in small open economy models (for a general discussion see Schmitt-Grohé and Uribe, 2003). Neumeyer and Perri (2005), for example, use a specification similar to (3), but with bond holdings relative to GDP. Finally, the profits of the financial intermediary and from production, $\xi_{t}$, are redistributed to households in a lump-sum way. Since the financial intermediary has zero marginal and fixed costs, and as production yields zero profits, $\theta_{t}=\xi_{t}$ holds in equilibrium.

A representative household maximizes (1) subject to (2) and (3), and a no-Ponzigame condition which prevents that the household accumulates excessive debt. ${ }^{5}$ Labor

\footnotetext{
${ }^{5}$ The presence of the transaction costs $\theta_{t}$ in the household's budget constraint (2) does not alter the structure of the no-Ponzi-game condition. To see this, iterate forward (2) by successively eliminating $b_{t+1+j}$ and note that $\theta_{t}$ enters the budget constraint additively separable.
} 
market clearing implies that $n_{t}=n_{t}^{d}$. The first-order conditions can be combined to

$$
\begin{aligned}
\left(1-\tau_{t}^{n}\right) w_{t} & =\nu n_{t}^{\varphi} c_{t}^{\sigma} \\
\frac{z_{t}}{R_{t}}+\tilde{\theta} b_{t+1} & =\beta E_{t}\left[\left(\frac{c_{t}}{c_{t+1}}\right)^{\sigma}\right] \\
1 & =\beta \frac{c_{t}^{\sigma}}{z_{t}} E_{t}\left[\frac{1}{c_{t+1}^{\sigma}}\left[1+\left(1-\tau_{t+1}^{k}\right) F_{k}\left(k_{t+1}, n_{t+1}, Z_{t+1}, a_{t+1}\right)\right]\right] \\
w_{t} & =F_{n}\left(k_{t}, n_{t}^{d}, Z_{t}, a_{t}\right) .
\end{aligned}
$$

Equation (5) shows that, other things equal, an increase in debt increases the interest rate due to higher transaction costs. Finally, the transversality conditions hold

$$
\lim _{t \rightarrow \infty} \beta^{t+1} E_{0}\left(c_{t+1}^{-\sigma} b_{t+1}\right)=0 \text { and } \lim _{t \rightarrow \infty} \beta^{t} E_{0}\left(c_{t}^{-\sigma} z_{t} k_{t+1}\right)=0
$$

\subsection{Government and resource constraint}

The government has to finance a stochastic stream of expenditures $g_{t}$ with law of motion $\ln \left(g_{t} / g\right)=\rho_{g} \ln \left(g_{t-1} / g\right)+\varepsilon_{t}^{g}, \quad \varepsilon_{t}^{g} \sim \mathcal{N}\left(0, \sigma^{g}\right)$. Its objective is described in the next section. It has access to flat-rate taxes on capital and labor income and can issue non-state-contingent bonds. Since $k_{0}$ is an inelastic tax base, I fix $\tau_{0}^{k}$ to rule out that the government collects non-distortionary revenues. Moreover, with constant returns to scale, (7) implies that $F\left(k_{t}, n_{t}^{d}, Z_{t}, a_{t}\right)-w_{t} n_{t}^{d}=k_{t} F_{k}\left(k_{t}, n_{t}, a_{t}, Z_{t}\right)$, such that revenues from capital taxes can be written as $\tau_{t}^{k} F_{k}\left(k_{t}, n_{t}, a_{t}, Z_{t}\right) k_{t}$. The budget constraint is

$$
g_{t}+b_{t}=\tau_{t}^{n} w_{t} n_{t}+\tau_{t}^{k} F_{k}\left(k_{t}, n_{t}, a_{t}, Z_{t}\right) k_{t}+\frac{z_{t} b_{t+1}}{R_{t}}+\frac{\kappa}{2}\left(\tau_{t}^{k}-\tau^{k}\right)^{2}
$$

where $\tau^{k}$ indicates the non-stochastic steady state of that variable, which is taken as given by the government. The last term on the RHS of (9) are capital tax adjustment costs. They can be motivated by the slow response of taxes to macroeconomic conditions, which possibly reflects inertia in the political and administrative process associated with changes in tax law. von Hagen and Harden (1995) and Wyplosz (2005) document a number of reasons why fiscal policy-unlike monetary policy-is likely to respond only sluggishly to the state of the economy. The main reason is that fiscal decisions need parliamentary approval, slowing and politicizing the process. Quite often, the parliament-sanctioned results are different from the government's initial intentions, and in extreme cases might yield no change in fiscal instruments at all. A standard assumption in the literature on structural vector autoregressions, for example, is that there is no discretionary contemporaneous response of fiscal policy to the business cycle (see Blanchard and Perotti, 2002; Beetsma and Giuliodori, 2011). 
Due to the same reasons, Farhi (2010) assumes that capital tax rates are predetermined. In his setup the delayed response of capital taxes together with the nonstate-contingency of government bonds ensures that markets are incomplete since it rules out that the government has sufficient instruments within period to perfectly insulate its budget from aggregate shocks. The strict assumption of predeterminancy is relaxed here. Capital taxes are allowed to (partially) respond within period. Nevertheless, the adjustment costs preserve the incomplete market structure as they prevent the large variations in ex post state-contingent capital tax rates which are required for replicating the complete market case. Thereby, they add to a realistic description of the incomplete market environment in which real world governments operate (see Marcet and Scott, 2009). Finally, an alternative formulation of the adjustment costs as $\kappa\left(\tau_{t}^{k} / \tau_{t-1}^{k}-1\right)^{2} / 2$ that does not depend on the assumption of $\tau^{k}$ being exogenously fixed yields qualitatively the same and quantitatively similar results. Also note that while adjustment cost functions have been used in other contexts, they are new in the literature on optimal fiscal policy.

The resource constraint of the economy reads

$$
F\left(k_{t}, n_{t}, a_{t}, Z_{t}\right)+k_{t}=c_{t}+g_{t}+z_{t} k_{t+1}+\frac{\kappa}{2}\left(\tau_{t}^{k}-\tau^{k}\right)^{2} .
$$

Then, for a given government policy a competitive equilibrium can be defined as

Definition 1 For a given government policy $\left\{\tau_{t}^{n}, \tau_{t}^{k}, b_{t+1}\right\}_{t=0}^{\infty}$ satisfying (9), a competitive equilibrium is a set of sequences $\left\{c_{t}, k_{t}, n_{t}, R_{t}, w_{t}, \theta_{t}, \xi_{t}\right\}_{t=0}^{\infty}$ satisfying (3)-(7), (10), $\theta_{t}=\xi_{t}$, and the transversality conditions for given exogenous processes $\left\{a_{t}, g_{t}, z_{t}\right\}_{t=0}^{\infty}$ and initial conditions $b_{0}, k_{0}$, and $\tau_{0}^{k}$.

\subsection{Policy problem}

The government has the same period utility function as the representative household but may have a different discount factor. Its objective is

$$
E_{0} \sum_{t=0}^{\infty}(\gamma \beta)^{t}\left(\frac{c_{t}^{1-\sigma}-1}{1-\sigma}-\frac{\nu n_{t}^{1+\varphi}}{1+\varphi}\right) .
$$

The parameter $\gamma$ is crucial for the analysis. In the baseline calibration I assume that $\gamma<1$, following Arrow and Kurz (1970), Bonis and Spataro (2005), Kumhof and Yakadina (2007), Aguiar et al. (2009), and Reis (2012). This assumption implies that the government values future utility less than the private sector. It can be seen as a short cut to modelling the underlying political-economy process explicitly that gives rise to public short-sightedness. Authors have employed different approaches. Persson 
and Svensson (1989), Alesina and Tabellini (1990), and Amador (2004), develop models where different parties exogenously alternate in power and an incumbent party with a low probability of remaining in power has a high discount rate. Azzimonti-Renzo (2007) endogenizes the probability of re-election, Battaglini and Coate (2008) show that porkspending implies a present bias of the government, and Nunes and Debortoli (2011) highlight the role of political disagreement about the allocation of public expenditure for public impatience. Finally, Aizenman (1992) derives a present-bias of the government from first principles by considering divided governments which lead to coordination failures and competitive externalities.

The specific formulation (11) with $\gamma \leq 1$ can be motivated as in Grossman and Van Huyck (1988). To account for the possibility that the government might loose office, suppose that it has a finite planning horizon of $h$ years, which corresponds to the prospective duration of the survival in power. The objective of the government would then be

$$
E_{0} \sum_{t=0}^{h} \beta^{t}\left(\frac{c_{t}^{1-\sigma}-1}{1-\sigma}-\frac{\nu n_{t}^{1+\varphi}}{1+\varphi}\right),
$$

where $h$ is a random variable defined over the nonnegative integers. If one further assumes that the sovereignty will terminate in any period with a constant probability $1-\gamma$, where $0 \leq \gamma \leq 1$, the termination of the sovereignty is a Poisson process with parameter $1-\gamma$ and the duration of the sovereignty is distributed as an exponential random variable whose expected value is $h=1 /(1-\gamma)$. The government would then maximize the expected discounted sum of future utility over an infinite horizon, but with utility discounted such as to reflect that $h$ can turn out to be less than $t$. Under these assumptions (12) could be re-written as (11). If $h \rightarrow \infty \Rightarrow \gamma \rightarrow 1$, that is, when the probability of loosing office converges to zero, the public and private rate of time discount coincide.

With this interpretation in mind, the problem of the government is defined as

Definition 2 The problem of the government is to maximize (11) over competitive equilibria by choosing sequences of tax rates and debt $\left\{\tau_{t}^{n}, \tau_{t}^{k}, b_{t+1}\right\}_{t=0}^{\infty}$ satisfying the government's budget constraint (9), for given exogenous processes $\left\{a_{t}, g_{t}, z_{t}\right\}_{t=0}^{\infty}$ and initial values $b_{0}, k_{0}$, and $\tau_{0}^{k}$.

There is a multiplicity of competitive equilibria indexed by different government policies. Definition 2 implies that the government chooses the equilibrium that maximizes (11) while taking into account the equilibrium reaction of the private sector. To solve the government's problem, I follow the methodology of the Ramsey primal approach and assume that the government adheres to commitments made in the past when choosing policy. There are several ways of motivating commitment: reputational 
mechanisms (see Chari and Kehoe, 1990), restrictions in the institution (see Chari and Kehoe, 1999), or a carefully chosen maturity structure of public debt (see Persson et al., 2006). To account for the fact that markets are incomplete, I follow the implementation of the Ramsey primal approach as in Aiyagari et al. (2002). Market incompleteness implies that it is necessary to derive a sequence of implementability constraints instead of a single implementability constraint as of period $t=0$. This sequence is derived in Appendix A.1 and reads

$$
\begin{gathered}
c_{t}^{-\sigma}\left(b_{t}+k_{t}+\left(1-\tau_{t}^{k}\right) F_{k}\left(k_{t}, n_{t}, a_{t}, Z_{t}\right) k_{t}\right) \\
=E_{t} \sum_{j=0}^{\infty} \beta^{j} c_{t+j}^{-\sigma}\left(c_{t+j}-\nu n_{t+j}^{1+\varphi} c_{t+j}^{\sigma}-\tilde{\theta} z_{t+j} b_{t+1+j}^{2}\right) .
\end{gathered}
$$

Except for the presence of capital and the term referring to the transaction costs, this formulation is as in Aiyagari et al. (2002). The restrictions on the set of allocations the government can achieve are then summarized by (6), (10), and (13). ${ }^{6}$ Since the sequence of implementability constraints (13) complicates the solution to the policy problem considerably, I again follow Aiyagari et al. (2002) and define the following recursively defined stochastic multiplier attached to (13): $\mu_{t}=\mu_{t-1} / \gamma+\psi_{t}$ with $\mu_{-1}=0$. With this definition the Lagrangian to the problem can be written recursively as ${ }^{7}$

$$
\begin{aligned}
L= & E_{0} \sum_{t=0}^{\infty}(\gamma \beta)^{t}\left\{\left(\frac{c_{t}^{1-\sigma}-1}{1-\sigma}-\frac{\nu n_{t}^{1+\varphi}}{1+\varphi}\right)\right. \\
& +\eta_{t}\left(F\left(k_{t}, n_{t}, a_{t}, Z_{t}\right)+k_{t}-c_{t}-g_{t}-z_{t} k_{t+1}-\frac{\kappa}{2}\left(\tau_{t}^{k}-\tau^{k}\right)^{2}\right) \\
& +\mu_{t}\left(c_{t}^{1-\sigma}-\nu n_{t}^{1+\varphi}-c_{t}^{-\sigma} z_{t} \tilde{\theta} b_{t+1}^{2}\right) \\
& -\psi_{t} c_{t}^{-\sigma}\left(b_{t}+\left[1+\left(1-\tau_{t}^{k}\right) F_{k}\left(k_{t}, n_{t}, a_{t}, Z_{t}\right)\right] k_{t}\right) \\
& \left.+\chi_{t}\left(E_{t}\left[z_{t}^{-1} c_{t+1}^{-\sigma}\left(1+\left(1-\tau_{t+1}^{k}\right) F_{k}\left(k_{t+1}, n_{t+1}, a_{t+1}, Z_{t+1}\right)\right)\right]-\beta^{-1} c_{t}^{-\sigma}\right)\right\}
\end{aligned}
$$

where $\chi_{t}$ and $\eta_{t}$ denote the multipliers attached to (6) and (10), respectively. The first order conditions to the policy problem are deferred to Appendix A.2. Notice that labor and capital taxes are treated differently in the Lagrangian. While the former can easily be substituted out using the intratemporal relation (4), for the latter this would complicate the policy problem given that (6) refers to an intertemporal margin. Hence the Lagrangian contains explicitly only the capital tax rate and the respective constraint. Nevertheless, the government optimizes implicitly with respect to labor taxes by choosing sequences for all variables in the Lagrangian, which then allow backing

\footnotetext{
${ }^{6}$ The intertemporal budget constraint of the government is satisfied by Walras' Law.

${ }^{7}$ See also the formulation of the Lagrangian in Kumhof and Yakadina (2007).
} 
out the sequence of optimal labor taxes from (4).

Now, an equilibrium under optimizing fiscal policy can be defined as

Definition 3 An equilibrium under optimizing fiscal policy is a set of sequences $\left\{b_{t}, c_{t}, n_{t}\right.$, $\left.k_{t}, R_{t}^{k}, \eta_{t}, \mu_{t}, \tau_{t}^{k}, \chi_{t}, \psi_{t}\right\}_{t=0}^{\infty}$ satisfying (6), (10), (14)- (19), $\mu_{t}=\mu_{t-1} / \gamma+\psi_{t}$, and $R_{t}^{k}=\left[1+\left(1-\tau_{t}^{k}\right) F_{k}\left(k_{t}, n_{t}, a_{t}, Z_{t}\right)\right]$, for given exogenous processes $\left\{a_{t}, g_{t}, z_{t}\right\}_{t=0}^{\infty}$ and initial values $b_{0}, k_{0}, \tau_{0}^{k}$, and $\mu_{-1}=0$.

Based on the definition, I will derive a proposition that characterizes the politically optimal level of debt and capital taxes in the non-stochastic steady state. The latter is defined as the long-run equilibrium in absence of shocks where $a_{t}=a, g_{t}=g$, and $z_{t}=z$ and allocations and multipliers are constant. The proposition is derived under the assumption that the solution to the policy problem converges to a steady state, which implies that the Lagrangian multipliers converge to a finite limit. This assumption is verified numerically for the baseline and alternative calibrations (see below). In addition, part (b) of the proposition relies on one (strong) parametric assumption. Specifically, I set $\sigma=0$. This assumption is necessary for deriving closed form solutions, which are intended to provide a first intuition, and is made only here. It is relaxed in the quantitative investigation of the next section that is the core of the paper. There, it is shown numerically that alternative values of $\sigma$ yield qualitatively the same results. Finally, given that $\sigma=0$, I set $z=1$ to stay consistent with balanced growth.

Proposition 1 In a steady state under optimizing fiscal policy

(a) Government debt is positive if $\gamma<1: b=(1-\gamma) \beta /(2 \tilde{\theta})>0$,

(b) For $\sigma=0$, the tax rate on capital is positive if $\gamma<1: \tau^{k}>0$.

The proposition shows that if the government discounts the future at higher rates than the private sector it accumulates debt and taxes capital in steady state. ${ }^{8}$ Moreover, it can be shown that

Corollary 1 Under optimizing fiscal policy in the steady state

(a) Government debt increases when $\gamma$ declines: $\partial b / \partial \gamma<0$,

(b) At $\gamma=1$, the tax rate on capital increases when $\gamma$ declines: $\partial \tau^{k} /\left.\partial \gamma\right|_{\gamma=1}<0$.

The proofs are relegated to Appendix A.3. The results for debt are closely related to Kumhof and Yakadina (2007) who obtain similar results in an economy without capital. They show that the level of debt depends on the difference between the private and the public discount rate and the size of transaction costs. In the limit, $b \rightarrow 0$ for $\tilde{\theta} \rightarrow \infty$ and

\footnotetext{
${ }^{8}$ Part (b) does not depend on the presence of capital tax adjustment costs as they drop out in steady state. Alternatively, assume that $\kappa=0$ and note that the proof is the same.
} 
$b \rightarrow \infty$ for $\tilde{\theta} \rightarrow 0$. This illustrates the role of the transaction costs. They function as a continuous debt limit and prevent the path of debt from exploding, ensuring an interior solution to the policy problem. The debt limit binds earlier than the fixed lower and upper debt limits in Aiyagari et al. (2002) and Farhi (2010), and than the natural debt limit. Fixed limits are not suited for the purpose of this paper, however, as $\gamma<1$ would imply a corner solution with the economy operating at the upper debt limit. This in turn would prohibit a symmetric analysis of fiscal policy in response to shocks. Finally, the natural debt limit of households will not be reached for $\gamma<1$ as this parameter range induces the government to issue debt.

The results for capital taxes show that a higher public than private rate of time discount implies a positive tax on capital income and that this tax increases in the difference between the rates of time discount. An intuition for these results can be gained from (6) in steady state which reads

$$
\frac{1}{\beta}=1+\left(1-\tau^{k}\right) F_{k}
$$

If $\tau^{k}>0$ then $F_{k}$ is higher relative to a case of $\tau^{k}=0$, indicating that the capital stock is lower. This reflects the impatience of the government which values the long-run capital stock less than private agents and uses capital taxes to drive a wedge between the intertemporal rate of substitution and the marginal rate of transformation of consumption to align the latter with its own time preferences. In other words, it taxes future consumption. The quantitative implications of these findings are discussed next.

\section{Data and calibration of the model}

The model is calibrated to a yearly frequency using a sample of 42 countries for the period 1985-2014. The sample includes data on capital and labor tax rates, government debt, government expenditures, output, and private consumption. Average effective tax rates are constructed following the methodology of Mendoza et al. (1994). The selection of countries is dictated by the availability of the data for government debt and the data needed for the computation of tax rates. The econometric analysis in Section 5 uses several measures of political instability and the quality of political institutions. It also employs variables which control for structural characteristics of a country such as the size of the population and GDP as well as the percent of rural, elderly, and urban population. In an out-of-sample sensitivity analysis it additionally uses tax and debt data for 13 countries for the period 1964-1983. Appendix B provides a list of the countries, data definitions, and sources.

A central implication of the previous section is that the long-run level of debt and 
capital taxes are jointly driven by, among others, the public rate of time discount. Therefore, a first way to confront the model's predictions with the data-and to obtain an impression of the main data used-is to analyze the empirical distributions of capital taxes and debt ratios. Figure 1 shows the distributions of country-year observations for both variables focusing on the three largest countries in the sample. Two observations stand out. First, the level of capital taxes and debt/GDP, as well as their dispersion differs substantially across Germany, the US, and Japan. Second, across the three countries, higher capital taxes tend to be associated with higher debt ratios.
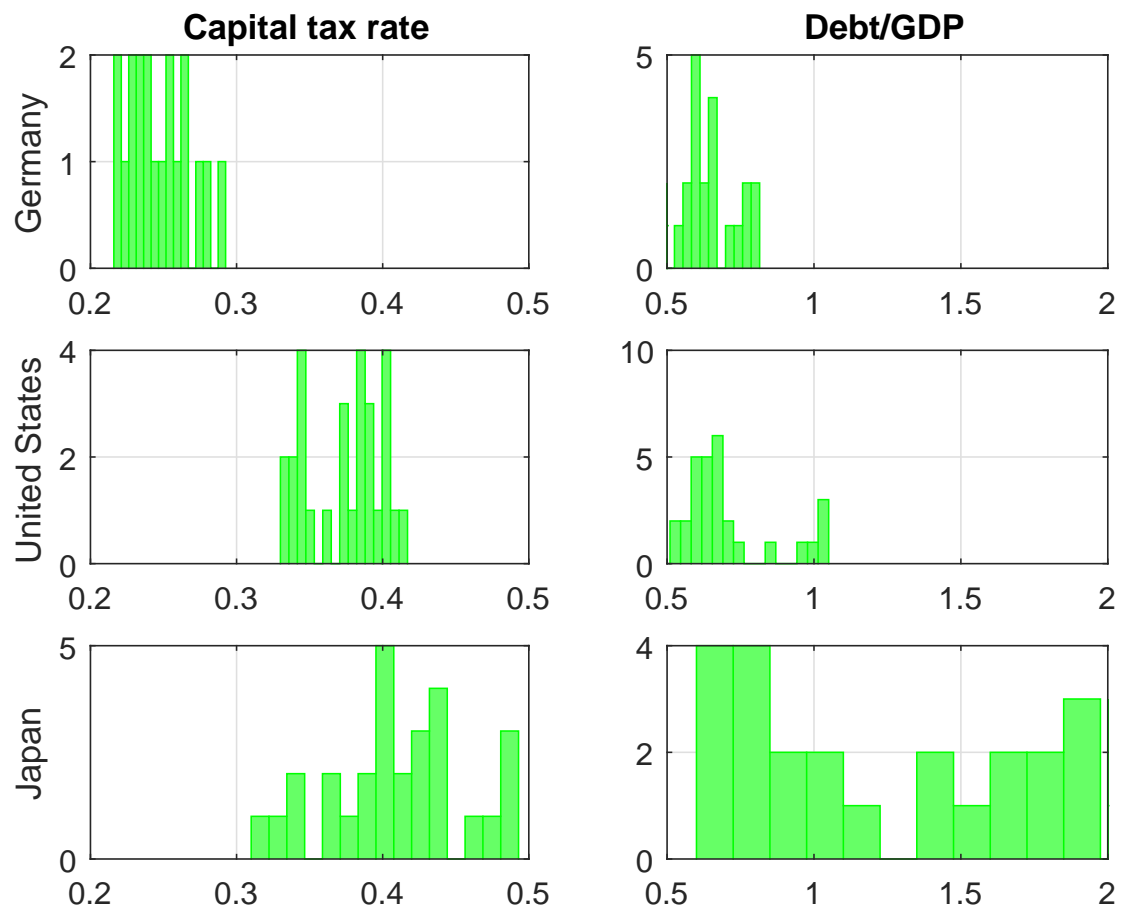

Figure 1: Empirical distributions of capital taxes and debt/GDP in Germany, US, and Japan. Notes: The figure shows histograms of annual observations of capital tax rates and debt ratios for these three countries for the sample period 1985-2014.

The second observation holds more generally across all countries. The correlation between the country-specific means of capital taxes and debt is 0.31 . Figure 2 plots the means against each other. The estimated slope is 0.12 and significant at the $10 \%$ level according to robust standard errors. This suggests a significant positive relation between long-run capital taxes and debt. Together, these observations provide first indirect support for one of the model's main assumptions, government short-sightedness, and its implications, positive capital taxes and debt.

Another way of testing them is to compare simulated moments from the model to their empirical counterparts. To this end, I conduct a Bayesian prior predictive analysis (see Faust and Gupta, 2012), conditional on several calibrated parameters. Specifically, 


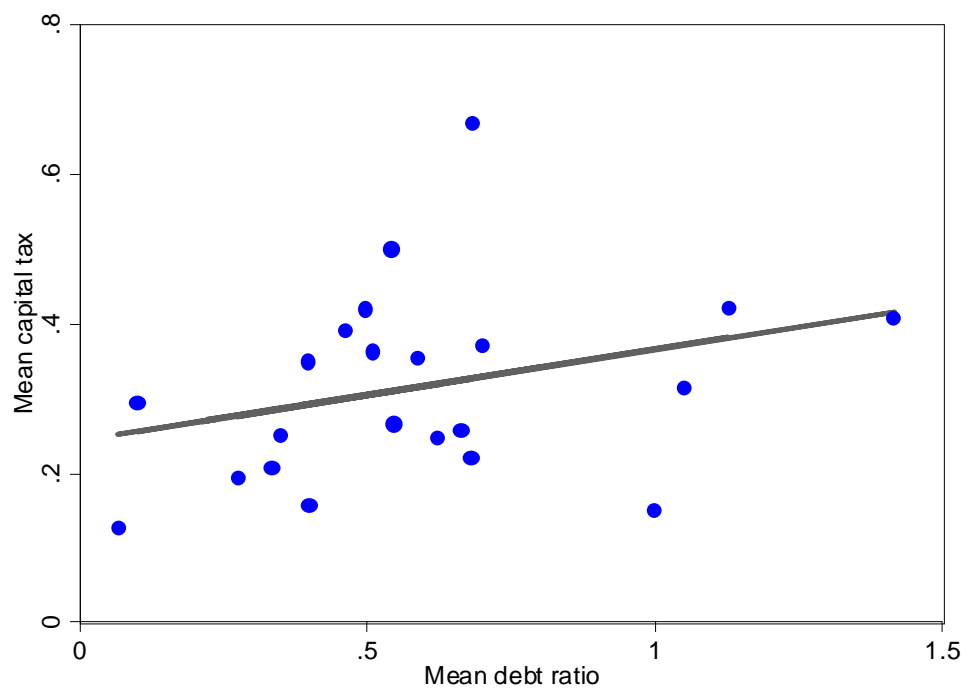

Figure 2: Capital taxes and debt ratios. Notes: The figure shows country-specific mean capital taxes and mean debt ratios over the period 1985-2014.

I calibrate the model and then introduce uncertainty around several parameters of interest. The simulated distributions can then be interpreted as coming from a crosssection of countries with some heterogeneity, consistent with the panel dimension of the data. Technically, they show the likelihood of observing the moments of interest in repeated samples coming from the model and the prior. Alternatively, assuming the same parameters across countries would imply that only the stochastic processes generate the simulated distributions.

For the baseline calibration without parameter uncertainty, I estimate the following regression by pooled OLS: $\hat{g}_{t}=\breve{\rho}_{g} \hat{g}_{t-1}+u_{t}$, where $\hat{g}_{t}$ denotes the HP cyclical component of government consumption using a HP parameter value of 6.25 for the annual frequency. The estimates imply values of $\rho_{g}=0.082$ and $\sigma^{g}=0.031$. Further, I set $g=0.065$ to match the GDP ratio of government expenditures, including public investment and excluding social security contributions and interest payments. The deterministic gross growth rate is $z=1.019$, consistent with its data average. The autocorrelation of transitory and permanent technology shocks are $\rho_{a}=0.77$ and $\rho_{z}=0.80$, respectively, and the standard deviation of innovations to the latter is $\sigma^{z}=0.03$, following GarcíaCicco et al. (2010). The standard deviation of innovations to stationary productivity is set to $\sigma^{a}=0.016$ such that the standard deviation of output matches that of the HP cyclical component of output in the data.

Regarding preferences, the household's discount factor is $\beta=0.98$ and, consistent with balanced growth, the inverse of the intertemporal elasticity of substitution is set 
to $\sigma=1$. The inverse of the Frish labor supply elasticity is assumed to be $\varphi=1$, following Trabandt and Uhlig (2011). The transaction cost parameter is calibrated to $\tilde{\theta}=0.05$ based on a steady state relation between the interest rate and debt which reads $z / R+\tilde{\theta} b=\beta$ (see 5 ). Solving for $R$, taking logs, and using the approximation $r \approx \log (R)$, where $r$ denotes the net interest rate, yields the following approximation:

$d r / d b \approx \tilde{\theta} /(\beta-\tilde{\theta} b) \approx \tilde{\theta}$ when $\tilde{\theta}$ is small. The chosen value implies an increase in the interest rate of one basis point for an increase in debt by one percent of GDP, in line with conservative estimates of the elasticity of interest rates with respect to debt (see Gale and Orszag, 2003; Engen and Hubbard, 2004; Laubach, 2009). Finally, the production function is $F\left(K_{t}, n_{t}, a_{t}, Z_{t}\right)=a_{t} K_{t}^{\alpha}\left(Z_{t} n_{t}\right)^{1-\alpha}-\delta K_{t}$ with $\alpha=0.33$ and $\delta=0.1$, following King and Rebelo (1999). As the last two parameters are originally calibrated to the US, I also consider alternative calibrations in the sensitivity analysis.

Given these parameters, I jointly choose a weight for working time in utility of $\nu=22.48$ and a (quasi) discount factor of the government of $\gamma=0.979$. These values imply $n=0.2$ and $\tau^{k}=0.31$. The latter figure replicates the average capital tax rate of $31 \%$ in the sample. Finally, the parameter governing the size of capital tax adjustment costs can be set to $\kappa=0.015$ to match the average standard deviation of capital taxes as this parameter has only limited effects on the moments of other variables.

Finally, I introduce uncertainty around several key parameters by specifying independent prior distributions consistent with their theoretically admissible domains and with means as in the baseline calibration. The variances are largely in line with the literature (see Lubik and Schorfheide, 2005) and chosen such that the parameter draws are likely to fall within the determinacy region. To allow for the possibility that governments have different discount factors, I specify a beta distribution for the (quasi) government discount factor $\gamma$. Moreover, to accommodate potentially alternative government spending and technology processes across countries, I use beta distributions on the first-order autocorrelation coefficients of the shocks, and inverse gamma distributions for the standard deviation of their innovations. Table 1 summarizes the parameter values of the calibration and the prior distributions.

\section{Quantitative properties of the model}

This section first evaluates the model's success in matching the empirical distributions of fiscal variables. It then explains the main findings by analyzing the effect of the government's discount factor on the simulated means, and by characterizing the dynamic implications of key parameters. The dynamics help understand the model-implied standard deviations. Finally, it discusses the role of the main model features in producing the simulated moments. To obtain the simulated distributions, I take 10,000 draws 
Table 1: Calibration and priors for yearly frequency.

\begin{tabular}{llll}
\hline \hline Parameter & Value & Description & Prior distr. (mean,sd.) \\
\hline$\beta$ & 0.981 & Household discount factor & \\
$\gamma$ & 0.979 & Quasi public discount factor & beta $(0.979,0.005)$ \\
$\nu$ & 22.4778 & Weight of labor in utility & \\
$\sigma$ & 1 & Inv. intert.elast. substitution & \\
$\varphi$ & 1 & Inv. Frisch labor supply elast. & \\
$n$ & 0.2 & Working time in steady state & \\
$\tilde{\theta}$ & 0.05 & Transaction cost parameter & \\
$\kappa$ & 0.006 & Capital tax adjustment costs & \\
$\alpha$ & 0.33 & Production elasticity capital & \\
$\delta$ & 0.1 & Rate of depreciation & \\
$z$ & 1.019 & Deterministic gross growth rate & \\
$\rho_{g}$ & 0.082 & AR(1) gov. consump. shocks & $\operatorname{beta}(0.082,0.05)$ \\
$\rho_{a}$ & 0.765 & AR(1) stationary techn. shocks & $\operatorname{beta}(0.765,0.1)$ \\
$\rho_{z}$ & 0.800 & AR(1) permanent techn. shocks & $\operatorname{beta}(0.800,0.1)$ \\
$\sigma^{g}$ & 0.031 & Sd. inn. gov. consumption & $\operatorname{invg}(0.031, \infty)$ \\
$\sigma^{a}$ & 0.016 & Sd. inn. station. technology & $\operatorname{invg}(0.016, \infty)$ \\
$\sigma^{z}$ & 0.030 & Sd. inn. perm. technology & $\operatorname{invg}(0.030, \infty)$ \\
\hline \hline
\end{tabular}

from the prior distributions and for each compute the non-stochastic steady state of the model. In this way I also verify numerically the assumption of the proposition that the model converges to a steady state where the multipliers converge to a finite limit. Then, I linearize the model around the steady state and simulate it with all three types of shocks for 1030 periods and keep the last 30, consistent with the time-dimension of the panel data. If applicable, the empirical moments are based on real per capita series. Finally, except when looking at means, both model-generated and observed data are HP filtered, following King and Rebelo (1999).

\subsection{Empirical and model-implied distributions}

Figure 3 shows the actual and simulated distributions of capital taxes and debt, and of the correlation between capital taxes and labor taxes. The empirical distributions show country-year observations for capital taxes and debt, and country observations for correlations, for all countries in the sample (not only for Germany, Japan, and the US as before). The model generally performs well in replicating the empirical distributions of capital taxes and debt/GDP. In particular, it closely matches the means and standard deviations of both variables. For capital taxes, the model-implied distribution tends to be more concentrated. Moreover, both empirical distributions seem to be right-skewed, whereas for the simulated distributions this is only the case for the debt ratio. As a first cross-check, the bottom row shows that the model also roughly matches a feature 
of the data that is not in the modelling focus; a positive correlation between labor taxes and capital taxes. Both distributions have most mass in the positive domain, although the model overpredicts the actual correlations.
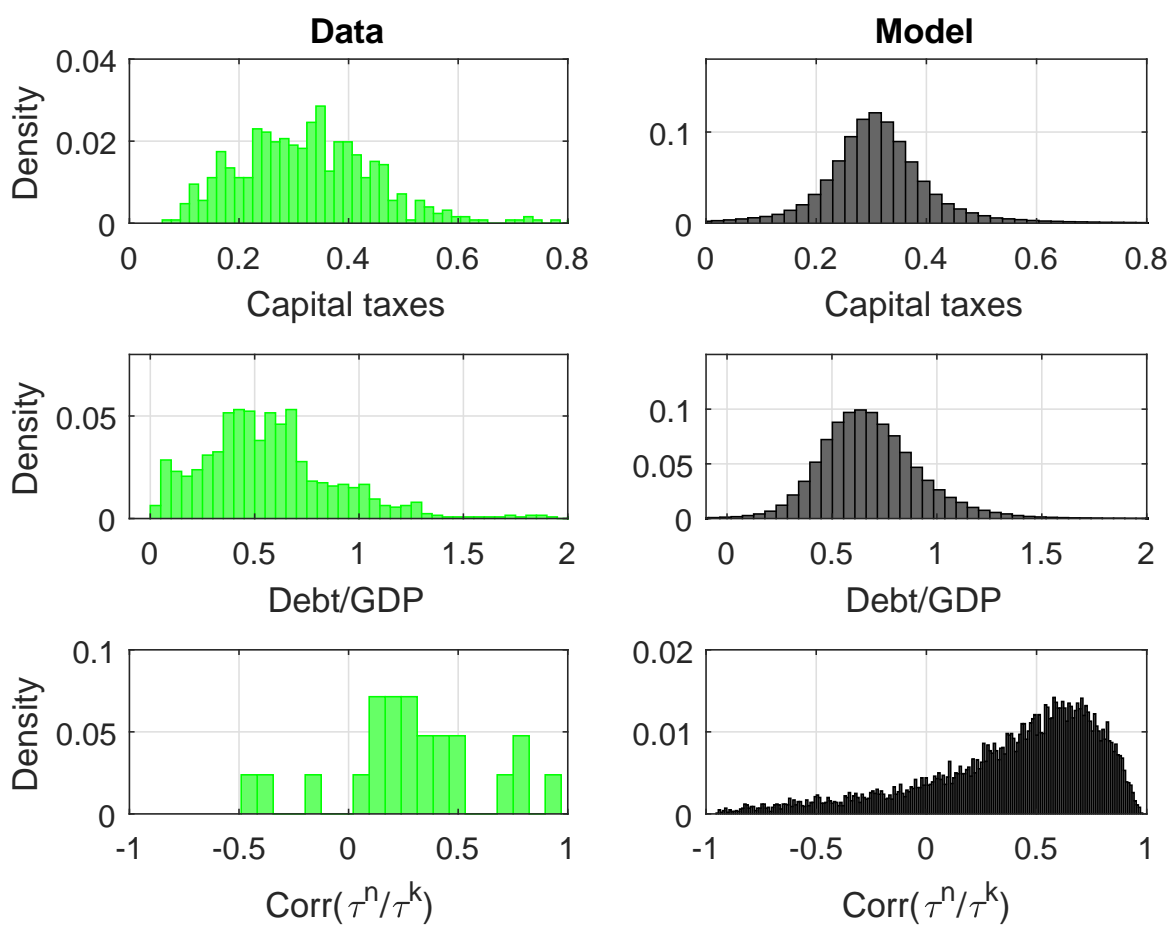

Figure 3: Empirical and simulated distributions. Notes: The figure shows the actual and the model-implied distributions of capital taxes, debt/GDP, and of the correlation between capital taxes and labor taxes. The empirical distributions show observations for a sample of up to 42 countries for the years 1985-2014. The simulated distributions are generated from 10,000 draws from the prior distributions and simulation lengths of 30 periods after burn-in.

Next, I assess whether the model also captures differences in means of capital taxes and debt across countries. For each draw from the prior distributions, I compute means over the given simulation horizon and plot their distribution in Figure 4 (black bars), together with the empirical country-specific means of taxes and debt (green bars). The simulated distributions of means reflects the differences in parameter values across simulations. The densities cover the variance of capital taxes and debt across countries. They are slightly more concentrated and show that the model has some difficulty in generating the low levels of debt observed in some countries. In contrast, the model fails to match the variance in mean labor taxes across countries.

To test more formally whether the model is able to replicate the moments in the data, I compute the means and 16th and 84th percentiles of the distributions in Figure 4. They are summarized in Table 2, where I add the same statistics for consumption to judge the ability of the RBC model underlying the optimal fiscal policy framework to replicate 

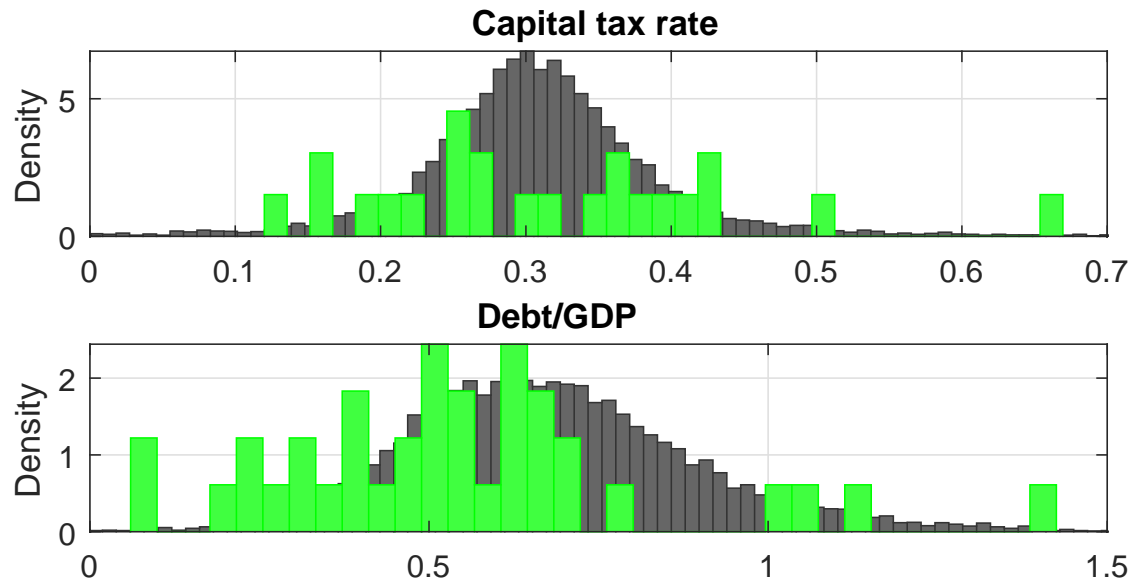

Labor tax rate

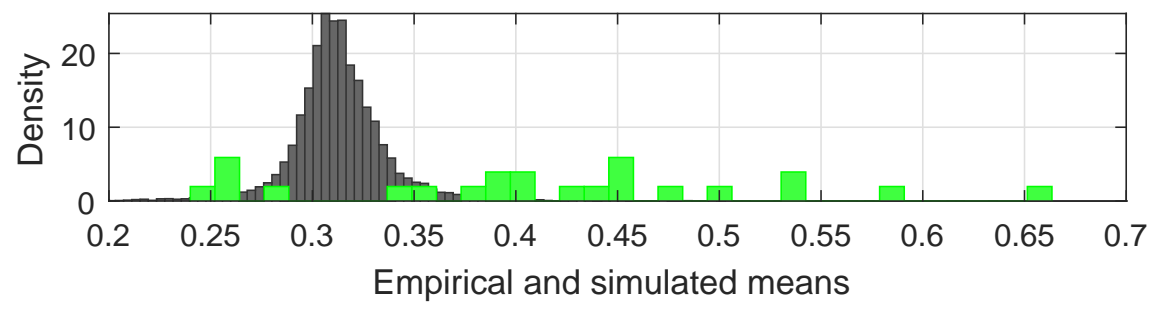

Figure 4: Simulated and empirical means. Notes: The figure shows the distribution of countryspecific means (green) and simulated means (black) of capital taxes, debt/GDP, and labor taxes. The simulated means are based on 10,000 draws from the prior distributions and a simulation length of 30 periods after burn-in.

standard business cycle features. Moments for which the inner 68 percentiles of the empirical and simulated distributions overlap are indicated by one asterisk (*). Moments for which the inner 68 percentiles of the predictive density contains the empirical mean are indicated by two asterisks $(* *)$. As already suggested by the previous two figures, the model indeed performs well in matching the level of capital taxes and debt. It is likely to observe such levels for both variables if the data are sampled from the model and the prior. On the other hand, there is only a small probability that the model generates the high level of labor taxes observed in reality. Here, the overlap of the inner 68 percentiles is rather due to the high dispersion of labor taxes across countries than a success of the model, which tightly predicts lower mean labor taxes.

Regarding second moments, the probabilities are relatively high of observing the empirical standard deviations of capital taxes, labor taxes, and consumption in repeated sampling from the model and the prior. For capital taxes this should not be too surprising given that the calibration of the capital tax adjustment cost parameter $\kappa$ is chosen such as to match this moment. Nevertheless, the results show that the model also generates standard deviations of the other variables that are similar to the ones 
Table 2: Empirical and model-implied moments.

\begin{tabular}{|c|c|c|c|c|c|}
\hline & & Capital taxes & Debt/GDP & Labor taxes & Consumption \\
\hline Mean & $\begin{array}{l}\text { Data } \\
\text { Model }\end{array}$ & $\begin{array}{l}0.314 \\
{[0.196,0.419]} \\
0.308^{* *} \\
{[0.245,0.370]}\end{array}$ & $\begin{array}{l}0.547 \\
{[0.298,0.712]} \\
0.688^{* *} \\
{[0.479,0.886]}\end{array}$ & $\begin{array}{l}0.411 \\
{[0.264,0.529]} \\
0.313^{*} \\
{[0.296,0.329]}\end{array}$ & \\
\hline $\begin{array}{l}\text { Standard } \\
\text { deviation }\end{array}$ & $\begin{array}{l}\text { Data } \\
\text { Model }\end{array}$ & $\begin{array}{l}0.008 \\
{[0,0.016]} \\
0.009^{* *} \\
{[0.004,0.012]}\end{array}$ & $\begin{array}{l}0.028 \\
{[0.018,0.039]} \\
0.015^{*} \\
{[0.007,0.020]}\end{array}$ & $\begin{array}{l}0.004 \\
{[0,0.008]} \\
0.005^{* *} \\
{[0.002,0.007]}\end{array}$ & $\begin{array}{l}0.023 \\
{[0.009,0.033]} \\
0.034^{* *} \\
{[0.015,0.048]}\end{array}$ \\
\hline $\begin{array}{l}\text { Relative } \\
\text { standard } \\
\text { deviation } \\
\text { to output }\end{array}$ & Model & $\begin{array}{l}0.593 \\
{[0,1.333]} \\
0.485^{*} \\
{[0.357,0.591]}\end{array}$ & $\begin{array}{l}1.681 \\
{[0.635,2.338]} \\
0.800^{*} \\
{[0.561,0.995]}\end{array}$ & $\begin{array}{l}0.261 \\
{[0,0.500]} \\
0.246^{* *} \\
{[0.126,0.354]}\end{array}$ & $\begin{array}{l}1.169 \\
{[0.763,1.559]} \\
1.820^{* *} \\
{[1.078,2.474]}\end{array}$ \\
\hline $\operatorname{AR}(1)$ & $\begin{array}{l}\text { Data } \\
\text { Model }\end{array}$ & $\begin{array}{l}0.078 \\
{[-0.142,0.298]} \\
0.237^{* *} \\
{[0.073,0.390]}\end{array}$ & $\begin{array}{l}0.198 \\
{[-0.045,0.474]} \\
0.225^{* *} \\
{[0.022,0.423]}\end{array}$ & $\begin{array}{l}0.044 \\
{[-0.132,0.193]} \\
0.067^{* *} \\
{[-0.116,0.246]}\end{array}$ & $\begin{array}{l}0.178 \\
{[0.053,0.350]} \\
0.006^{* *} \\
{[-0.167,0.183]}\end{array}$ \\
\hline $\begin{array}{l}\text { Correlation } \\
\text { with } \\
\text { government } \\
\text { expenditures }\end{array}$ & $\begin{array}{l}\text { Data } \\
\text { Model }\end{array}$ & $\begin{array}{l}-0.062 \\
{[-0.346,0.255]} \\
0.201^{*} \\
{[-0.028,0.439]}\end{array}$ & $\begin{array}{l}-0.017 \\
{[-0.314,0.29]} \\
-0.267^{*} \\
{[-0.510,-0.027]}\end{array}$ & $\begin{array}{l}-0.099 \\
{[-0.379,0.167]} \\
0.015^{* *} \\
{[-0.174,0.215]}\end{array}$ & $\begin{array}{l}0.136 \\
{[-0.271,0.517]} \\
-0.031^{* *} \\
{[-0.235,0.157]}\end{array}$ \\
\hline $\begin{array}{l}\text { Correlation } \\
\text { with output }\end{array}$ & $\begin{array}{l}\text { Data } \\
\text { Model }\end{array}$ & $\begin{array}{l}0.031 \\
{[-0.206,0.291]} \\
-0.527^{*} \\
{[-0.850,-0.194]}\end{array}$ & $\begin{array}{l}-0.511 \\
{[-0.679,-0.322]} \\
-0.490 * * \\
{[-0.806,-0.202]}\end{array}$ & $\begin{array}{l}0.064 \\
{[-0.208,0.348]} \\
-0.723 \\
{[-0.842,-0.591]}\end{array}$ & $\begin{array}{l}0.683 \\
{[0.428,0.871]} \\
0.819^{*} \\
{[0.708,0.943]}\end{array}$ \\
\hline
\end{tabular}

Note: The table shows selected moments of country-specific mean capital taxes, debt/GDP, labor taxes, and consumption in the data and simulated with the model based on 10,000 draws and simulation length of 30 after burn-in. The values in brackets show the 16th and 84th percentiles. * indicates that the inner 68 percentiles of the data and model-implied distributions overlap. ** indicates that the inner 68 percentiles of the model-implied distribution contains the data mean.

observed, albeit the prior density for debt/GDP being centered somewhat left of the empirical mean. Similarly, the model-implied standard deviations relative to output are mostly close to their empirical counterparts. Only for debt/GDP the probability is small that the model produces the sample moment. Regarding the autocorrelation coefficients, the predictive densities assign relatively high probabilities to the parameter space around the empirical moments. Finally, the model does an acceptable job of matching the correlations with government expenditure shocks, but has difficulty in replicating the correlations with output. While the latter is roughly zero in the data for both tax instruments, the model predicts negative correlations. This discrepancy suggests the existence of other frictions in real fiscal policy setting processes which prevent a countercyclical response of taxes. 
All in all, the table shows that the theoretical mechanisms at the heart of the model imply quantitatively plausible results. Specifically, a two percentage points difference between the public and private discount rate allows the model to perfectly match the average capital tax rate in the sample. To put this number into perspective, it implies that the expected planning horizon of the government is $h=1 /(1-\gamma)=48.2$ years, approximately the working lifetime of two generations. Hence, the model does not rely on extreme assumptions to match the data. Instead small differences in discount rates generate relevant effects. Moreover, the neoclassical growth model provides a reasonable point of departure for a quantitative analysis of fiscal policy as it is consistent with most consumption moments.

\subsection{Cross-country dispersion in mean capital taxes and debt/GDP}

Which model features explain the good fit of the data? To answer this question, Figure 5 plots the effect of increasing the net rate of time discount of the government, $\varpi=$ $1 /(\gamma \beta)-1$, by reducing $\gamma$ on the simulated means of capital taxes, the debt ratio, and labor taxes. The simulation for each value of $\gamma$ is conducted as outlined above, with the exception that the uncertainty around $\gamma$ is set to zero to clearly isolate its effects. The solid line shows the results for the baseline calibration and priors. At the very left the public and private discount rates coincide $(\gamma=1)$ and mean capital taxes are roughly zero. The same holds for debt. Going to the right, both means increase quickly. At $\varpi=0.075$ capital taxes and debt/GDP exceed $40 \%$ and $150 \%$, respectively. In contrast, the increase in mean labor taxes is relatively muted.

To clarify that $\gamma<1$ is at the heart of generating non-zero capital taxes, and not the choice of $\sigma=1$ as in Lansing (1999), I also consider a calibration with $\sigma=\varphi=2 .{ }^{9}$ To make the comparison to the baseline as clean as possible, I adjust the weight of labor in utility to $\nu=718.8$ to obtain a steady state working time of $n \approx 0.2$ for $\gamma=0.979$, but leave all other parameters unchanged. The dashed line shows that the effect of $\gamma$ on mean tax rates and debt is qualitatively the same as before. Quantitatively, the effect is stronger on capital taxes and weaker on labor taxes, while it is similar for the debt ratio. The smaller effect on labor taxes reflects the direct impact of $\varphi$ on the elasticity of the labor tax base, whereas the effect of $\sigma$ on the elasticity of the capital tax base is only indirectly through consumption. Now a value of $\varpi=0.075$ yields mean capital taxes of more than $60 \%$. As mean capital taxes range between $13 \%$ in Estonia and $67 \%$ in Portugal, and mean debt ratios between $6 \%$ in Estonia and 141\% in Japan, the figure shows that the full cross-country dispersion in mean capital taxes and debt ratios can be replicated by changing $\gamma$.

\footnotetext{
${ }^{9}$ For this alternative parameterization of the utility function, the deterministic gross rate of growth is set to $z=1$.
} 

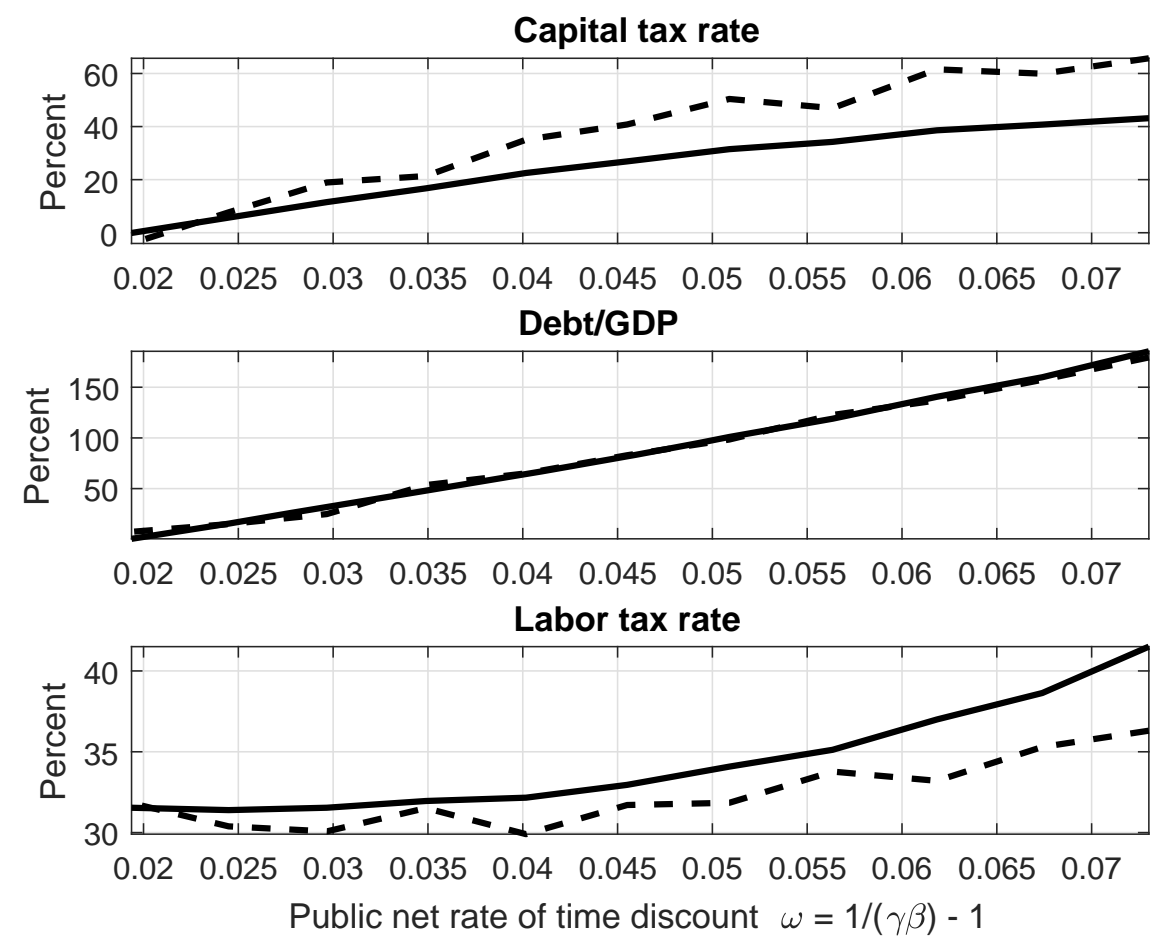

Figure 5: Simulated means for different public disount rates. Notes: The figure shows simulated means of capital taxes, debt/GDP, and labor taxes for alternative values of the net rate of discount of the government under the baseline calibration $(\sigma=1, \varphi=1$, solid line) and an alternative parameterization of the instantaneous utility function $(\sigma=2, \varphi=2$, dashed line).

\subsection{Impulse response analysis}

Now, I compute impulse responses to highlight the role of those model features that are particularly relevant for the dynamics of the fiscal instruments. While these shortrun transitions in response to shocks have only limited effects on the simulated means, they help understand what drives the model-implied second moments, in particular the standard deviations of capital taxes and debt. Figure 6 contains the responses to an innovation of one standard deviation to government consumption for the baseline calibration, and alternative parameter values of the (quasi) discount factor of the government $\gamma$, the transaction cost parameter $\tilde{\theta}$, and the size of the adjustment costs $\kappa .^{10}$ The effects of negative shocks to transitory and permanent technological progress are qualitatively similar but tend to be larger. They are deferred to Appendix C. The main reason for the stronger impact of these shocks is their higher persistence.

\footnotetext{
${ }^{10}$ The impulse responses refer to optimized policy from a timeless perspective. Since, strictly speaking, the economy never is in the non-stochastic steady states unless all shocks are zero for all $t$, the impulse responses can be thought of as an extraction from a simulation where only government spending shocks occur infrequently and all other shock-variances are zero. Further, the government is not allowed to reoptimize in response to each spending shock. Instead, the impulse responses are based on the assumption that the planner commits ex-ante and for all $t \geq 1$ to policy rules.
} 

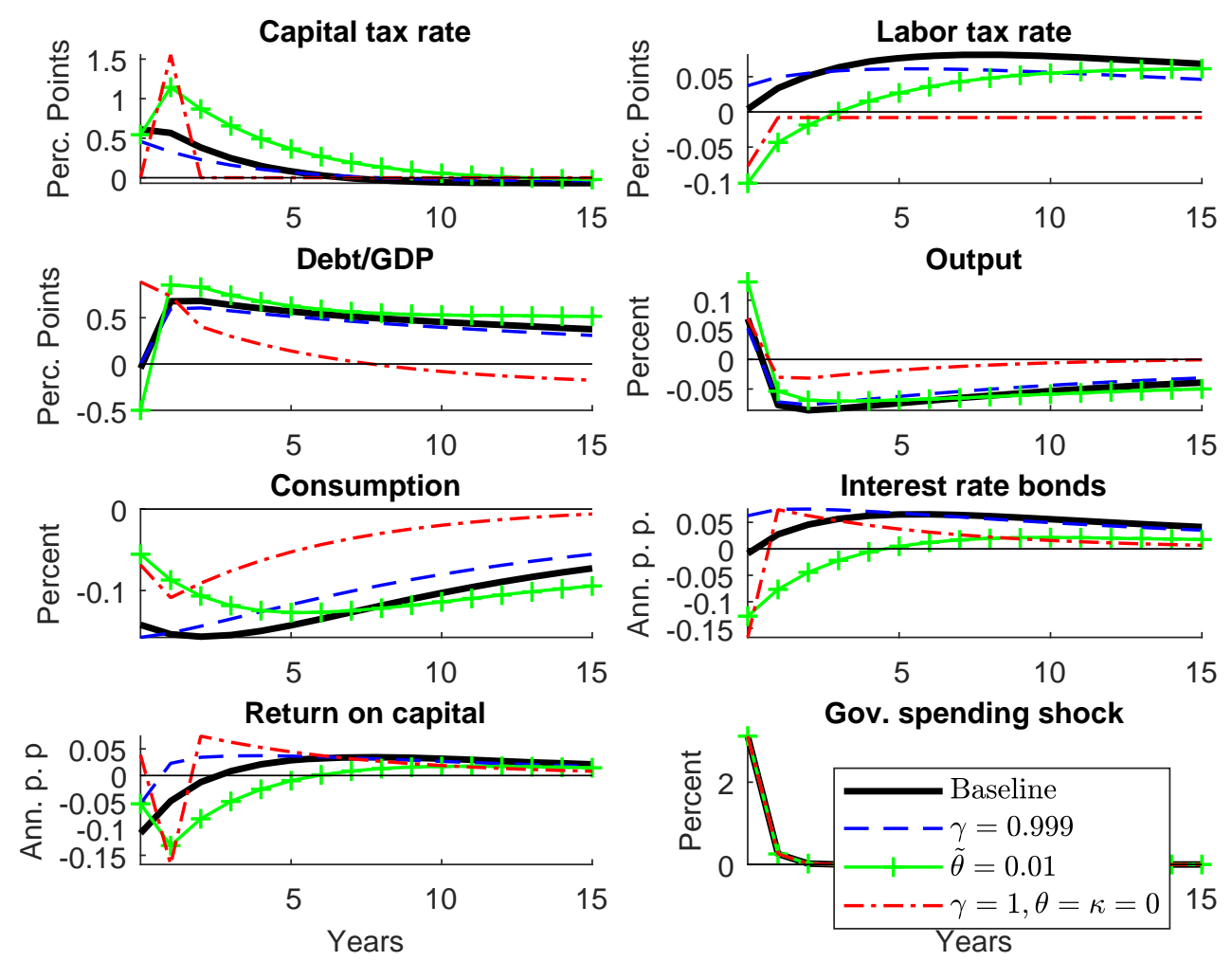

Figure 6: Impulse responses to a government spending shock of one standard deviation. Notes: The figure shows the impulse responses of selected variables for the baseline calibration (black line) and for different parameter values of the (quasi) discount factor of the government $\gamma=$ 0.999 (blue dashed line), bond transaction costs $\tilde{\theta}=0.01$ (green line with crosses), and for a calibration with $\gamma=1, \tilde{\theta}=\kappa=0$ (blue dash-dotted line).

The black line in Figure 6 refers to the baseline calibration. The first three panels show how the government uses its instruments. The tax rate on capital increases by about half of a percentage point on impact before it slowly returns to its long-run level, which is reached after approximately ten years. Capital taxes serve two purposes. First, they directly collect revenues and thereby help absorbing the expenditure shock. Second, they are used to manipulate the interest rate which lowers the costs of issuing new debt. In contrast, the response of labor taxes is muted and more sluggish, reflecting a tax smoothing motive. There is barely any reaction on impact and it increases by less than one tenth of a percentage point after five years. Debt also helps absorbing the shock. Given the initial increase in output, the debt ratio shows virtually no reaction on impact however. The increase in output in turn due to higher demand is only shortlived. GDP drops below steady state from period one onwards as higher taxes reduce both investment and working time. Public expenditures crowd out private consumption.

These dynamics are qualitatively not and quantitatively only mildly affected by the 
discount factor of the government. The blue dashed line shows a case in which time preferences are basically identical $(\gamma=0.999)$. The required increase in the tax rate on capital for a given absolute increase in government spending is smaller relative to the baseline calibration since the tax base is larger when long-run capital taxes are roughly zero. The resulting path of labor taxes is smoother, as well as the responses of output and consumption. The latter mirrors the government's stronger preference for nearby utility. Consumption is allowed to drop by more initially but reverts faster to trend. The comparison with the baseline calibration suggests that $\gamma$ has only limited effects on the volatility of the fiscal instruments, although the volatility tends to decrease.

In contrast, different assumptions about $\tilde{\theta}$ and $\kappa$ (and on the predeterminancy of capital taxes) have stronger effects on the dynamics and hence on second moments. To show this, I set the transaction cost parameter to a small number $(\tilde{\theta}=0.01$, green line with crosses). This has qualitatively the opposite effect on the responses of capital and labor taxes than when increasing $\gamma$. Lower transaction costs imply higher debt and taxes in steady state which depress the capital stock and output and thus require a larger increase in capital taxes. Moreover, lower transaction costs raise fluctuations in the debt ratio, which drops by more initially and then overshoots the baseline response. Lower values of $\tilde{\theta}$ will thus be mirrored in higher standard deviations of both variables.

The dash-dotted line shows a calibration similar to Farhi (2010) for comparison. I set $\gamma=1, \tilde{\theta}=0$, and $\kappa=0$. Moreover, capital taxes are predetermined. This assumption rules out that there are enough instruments available to the government within period to perfectly insulate its budget and thereby preserves market incompleteness. The figure shows that with $\kappa=0$ the response of capital taxes is larger than in the baseline case and lasts only for one period. Through its effect on interest rates this allows for a larger initial increase in debt, which then returns faster to its long-run level. These differential responses of capital taxes and debt relative to the baseline calibration indicate that lower values of $\kappa$ imply higher (lower) volatility of capital taxes (debt). ${ }^{11}$

\subsection{Sensitivity}

This section contains a sensitivity analysis. First, I reduce the importance of the three main model features, one-by-one, and compare the simulated moments to the baseline

\footnotetext{
${ }^{11}$ The tax rate on labor shows no variation after the decline on impact, reflecting a random walk component as in Aiyagari et al. (2002). The large initial drop can be understood through a savings argument. (With higher autocorrelation of government consumption, as in Farhi (2010), labor taxes increase above their initial level from period one onwards.) Anticipating the sharp increase in the tax rate on capital tomorrow, the household would work less today, building less capital and consuming more out of the existing capital stock. To prevent the deterioration of tomorrows tax base the government lowers the tax rate on labor today, inducing an increase in labor and output. Finally, note that for this calibration the model contains a unit root component. Some variables, such as labor taxes, do not return to their initial level, while all the other calibrations imply reversion to steady state.
} 
results and to the existing literature to clarify the relative contribution of each element to the model's performance. The results are contained in the left panels of Table 3. Numbers in bold/ italics/ underlined indicate moments that loose one asterisk/ loose two asterisks/ gain one asterisk, respectively, relative to the baseline calibration.

Table 3: Sensitivity analysis of model-implied moments.

\begin{tabular}{|c|c|c|c|c|c|c|c|}
\hline & & $\begin{array}{l}\text { Capital } \\
\text { taxes }\end{array}$ & $\begin{array}{l}\text { Debt/ } \\
\text { GDP }\end{array}$ & $\begin{array}{l}\text { Labor } \\
\text { taxes }\end{array}$ & $\begin{array}{l}\text { Capital } \\
\text { taxes }\end{array}$ & $\begin{array}{l}\text { Debt/ } \\
\text { GDP }\end{array}$ & $\begin{array}{l}\text { Labor } \\
\text { taxes }\end{array}$ \\
\hline & & \multicolumn{3}{|c|}{$\gamma=1$} & \multicolumn{3}{|c|}{$\alpha=0.25$} \\
\hline Mean & $\begin{array}{l}\text { Data } \\
\text { Model }\end{array}$ & $\begin{array}{l}0.314 \\
\mathbf{0 . 0 0 0}\end{array}$ & $\begin{array}{c}0.547 \\
\mathbf{- 0 . 0 0 2}\end{array}$ & $\begin{array}{c}0.411 \\
0.313^{*}\end{array}$ & $\begin{array}{l}0.314 \\
0.25 *\end{array}$ & $\begin{array}{c}0.547 \\
0.716^{* *}\end{array}$ & $\begin{array}{c}0.411 \\
0.356^{*}\end{array}$ \\
\hline S.D. & $\begin{array}{l}\text { Data } \\
\text { Model }\end{array}$ & $\begin{array}{c}0.008 \\
0.004^{*}\end{array}$ & $\begin{array}{l}0.028 \\
0.005\end{array}$ & $\begin{array}{c}0.004 \\
0.001^{*}\end{array}$ & $\begin{array}{c}0.008 \\
0.006^{* *}\end{array}$ & $\begin{array}{c}0.028 \\
0.017^{*}\end{array}$ & $\begin{array}{c}0.004 \\
0.005^{* *}\end{array}$ \\
\hline & & \multicolumn{3}{|c|}{$\tilde{\theta}=0.02$} & \multicolumn{3}{|c|}{$\alpha=0.4$} \\
\hline Mean & $\begin{array}{l}\text { Data } \\
\text { Model }\end{array}$ & $\begin{array}{c}0.314 \\
0.287^{* *}\end{array}$ & $\begin{array}{l}0.547 \\
\mathbf{1 . 7 5 8}\end{array}$ & $\begin{array}{c}0.411 \\
\underline{0.375}\end{array}$ & $\begin{array}{c}0.314 \\
0.277^{* *}\end{array}$ & $\begin{array}{c}0.547 \\
0.494^{* *}\end{array}$ & $\begin{array}{l}0.411 \\
0.243\end{array}$ \\
\hline S.D. & $\begin{array}{l}\text { Data } \\
\text { Model }\end{array}$ & $\begin{array}{c}0.008 \\
0.018^{* *}\end{array}$ & $\begin{array}{c}0.028 \\
\underline{0.034^{* *}}\end{array}$ & $\begin{array}{c}0.004 \\
0.003^{* *}\end{array}$ & $\begin{array}{c}0.008 \\
0.006^{* *}\end{array}$ & $\begin{array}{l}0.028 \\
0.010\end{array}$ & $\begin{array}{c}0.004 \\
0.005^{* *}\end{array}$ \\
\hline & & \multicolumn{3}{|c|}{$\kappa=0.0015$} & \multicolumn{3}{|c|}{$\delta=0.07$} \\
\hline Mean & $\begin{array}{l}\text { Data } \\
\text { Model }\end{array}$ & $\begin{array}{c}0.314 \\
0.257^{* *}\end{array}$ & $\begin{array}{c}0.547 \\
0.635^{* *}\end{array}$ & $\begin{array}{c}0.411 \\
0.313^{*}\end{array}$ & $\begin{array}{c}0.314 \\
0.275^{* *}\end{array}$ & $\begin{array}{c}0.547 \\
0.563^{* *}\end{array}$ & $\begin{array}{c}0.411 \\
0.262^{*}\end{array}$ \\
\hline S.D. & $\begin{array}{l}\text { Data } \\
\text { Model }\end{array}$ & $\begin{array}{c}0.008 \\
\mathbf{0 . 0 3 7}\end{array}$ & $\begin{array}{c}0.028 \\
0.013^{*}\end{array}$ & $\begin{array}{c}0.004 \\
0.002^{*}\end{array}$ & $\begin{array}{c}0.008 \\
0.006^{* *}\end{array}$ & $\begin{array}{l}0.028 \\
0.012\end{array}$ & $\begin{array}{c}0.004 \\
0.005^{* *}\end{array}$ \\
\hline
\end{tabular}

Note: The table shows means and standard deviations of capital taxes, debt/GDP, and labor taxes in the data and simulated with the model using 5000 draws from the prior distributions and a simulation length of 30 periods after burn-in. * indicates that the inner 68 percentiles of the data and model-implied distributions overlap. ${ }^{* *}$ indicates that the inner 68 percentiles of the model-implied distribution contains the data mean. Numbers in bold (italic) indicate that the model-implied moment under the alternative calibration looses two (one) stars relative to the baseline calibration. Numbers underlined indicate that the model-implied moment under the alternative calibration gains one star.

First, I set $\gamma=1$ to highlight the role of public discounting. The model now generates the standard result of average capital taxes close to zero, as in Farhi (2010). This implies that the calibration of $\gamma$ and not of the bond transaction or capital tax adjustment costs, which are the other two main modeling departures from Farhi (2010), are driving the result of positive long-run capital taxes. ${ }^{12}$ The transaction costs are necessary to obtain this result, however, as they prevent the path of debt from diverging

\footnotetext{
${ }^{12}$ Another difference is that the author uses a global method instead of looking at linearized dynamics around a steady state. This approach allows quantifying also a 'hedging term' in the setting of optimal capital taxes, which is absent here. The hedging term is quantitatively small as the author shows.
} 
if $\gamma<1$. Moreover, mean debt/GDP is zero as well for $\gamma=1$. This result is similar to the findings of Kumhof and Yakadina (2007) for the case of $\gamma \rightarrow 1$, but different to Aiyagari et al. (2002) who obtain large negative long-run debt for $\gamma=1$. This difference originates in the presence of the quadratic bond transaction costs, which make it too costly for the government to accumulate claims against the private sector. The case $\gamma=1$ also shows that, unlike in Lansing (1999), a value of $\sigma=1$ itself does not imply positive capital taxation. Finally, note that the model now imlies lower standard deviations of all three variables, as suggested by the impulse response analysis. Second, I set $\tilde{\theta}=0.02$ to illustrate the impact of lower bond transaction costs. While the simulated mean of capital taxes is hardly affected, the model now overpredicts the empirical debt ratio substantially as the costs of accumulating debt decline by a factor of 2.5. Similarly, the model predicts a higher volatility of the debt ratio than in the baseline calibration, as with lower transaction costs this instrument can absorb a larger share of the budgetary fluctuations. On the other hand, higher permanent debt ratios imply higher debt-servicing costs which requires higher labor taxes. Their level is now more in accordance with the data. Third, I set $\kappa=0.0015$ to analyze the effects of lower capital tax adjustment costs. As expected, the model implies substantially larger fluctuations in capital taxes, with the simulated standard deviation exceeding its empirical equivalent by far. Moreover, the volatility of labor taxes declines as capital taxes buffer more of the shocks.

In the right panels, I assess the sensitivity of the results to changing the production elasticity of capital or the rate of depreciation. The effects on means and standard deviation are relatively small in all cases. Finally, through unreported results, I aim at ruling out an alternative explanation for the effect of $\gamma$ on mean capital taxes. One suspicion could be that this relation is driven by a revenue-rather than a time preference-channel through the negative effect of $\gamma$ on debt. Since lower values of $\gamma$ imply higher debt servicing costs and given that labor taxes respond only modestly to changes in $\gamma$, it could be that capital taxes increase mainly because they have to bear the interest burden. This explanation can be ruled out by setting $\tilde{\theta}=5$ which virtually eliminates long-run debt while leaving mean capital taxes at 31 percent.

\section{Econometric analysis}

In this section I test explicitly whether politically more unstable countries feature higher levels of capital taxation and government debt. As the net rate of time discount of incumbent governments, $\varpi$, is unobservable I employ different measures of political 
instability as approximations. The empirical model is

$$
\text { dependent }_{i, t}=\Gamma \tilde{\varpi}_{i, t-1}+x_{i, t-1} \beta+u_{i, t}, \quad i=1, \ldots, N, \quad t=1, \ldots, T
$$

where dependent $t_{i, t}$ is either the tax rate on capital $\tau_{t}^{k}$ or the annual debt-to-GDP ratio $b_{t} / y_{t}, \tilde{\varpi}_{i, t}$ a measure of political instability, and $x_{i, t-1}$ a vector of control variables. Observations are indexed by both country $i$ and year $t$. The exogenous variables include a constant, possibly year and country fixed-effects, and a set of control variables discussed below. All non-dummy explanatory variables are lagged one period to reduce reverse causality concerns. The parameter of interest is $\Gamma$ and the expected sign is positive.

In the baseline and main specifications I use panel corrected standard errors to account for panel heteroskedacticity and contemporaneously as well as serially correlated errors, following Beck and Katz (1995). The autocorrelation is assumed to be common across countries. Panel heteroskedasticity and contemporaneous correlation are likely to arise in cross-country panels where the level of capital taxation and debt differs substantially across countries and where countries are potentially affected by correlated shocks. Autocorrelation is a main feature of tax and debt data.

As a preliminary analysis, Table 4 contains a simple specification with alternative measures of political instability. The dependent variable in panel (a) is the tax rate on capital and in panel (b) the debt ratio. Both models contain a common set of control variables indicated at the bottom of the table. In addition to country and year fixedeffects I correct for the shocks that drive the evolution of capital taxes and debt over time according to the model of Section 2. To obtain approximations of permanent and transitory technology shocks I estimate a common stochastic trend model for the 42 countries using Bayesian methods, following Lubik and Schorfheide (2005):

$$
\Delta y_{t}^{i, \text { observed }}=\varsigma+\Delta a_{t}^{i}+z_{t}, \quad \ln a_{t}^{i}=\ln a_{t-1}^{i}+\varepsilon_{t}^{a}, \quad \ln z_{t}=\rho_{z} \ln z_{t-1}+\varepsilon_{t}^{z},
$$

with country-specific stationary technology processes. ${ }^{13} \mathrm{I}$ use the estimates of $\ln a_{t}^{i}$ and $\ln z_{t}$ obtained from the Kalman smoother at the posterior mean. ${ }^{14}$ To obtain expenditure shocks, I employ the first log difference of observed government consumption.

The first column uses the preferred measure of political instability, which is based on the index for 'Political Stability and Absence of Violence' from the Worldwide Governance Indicators of the World Bank. This indicator reflects perceptions of the likelihood of political instability and/or politically-motivated violence, including terrorism. Orig-

\footnotetext{
${ }^{13}$ I specify a beta prior distribution for $\rho_{a}^{i}$ with mean 0.6 and standard deviation 0.2 , a uniform prior for $\rho_{z}$ on the interval $[0,1]$, a normal prior for $\varsigma$ with mean 2 and standard deviation 1 , and inverse gamma priors for $\varepsilon_{t}^{a}$ and $\varepsilon_{t}^{z}$ with mean 2 and infinite standard deviation.

${ }^{14}$ The following results are insenstitive to dropping these three control variables or to using bootstrap standard errors to deal with potential problems of generated regressors.
} 
inally, higher values correspond to higher stability. I therefore reverse the sign of the index for ease of interpretation in line with the previous section. Both point estimates are highly statistically significant. Consistent with the predictions of the model, politically more unstable countries feature higher capital taxes and government debt. The large $R^{2}$ in both panels indicates that the model provides a reasonable description of the behavior of capital taxes and debt across countries and time.

In Column (2), I use as alternative measure of instability the 'State Fragility Index' of the Center for Systemic Peace. This index is based on different subindices which score countries according to the political and economic legitimacy and effectiveness, among others. Higher values imply worse outcomes. Again, the relation between the index and the dependent variable is highly significant in both panels. Higher fragility is associated with higher capital taxes and government debt. In the remaining columns, I return to the Worldwide Governance Indicators. This data set provides-in addition to the measure of political instability-the following five indicators of governance: voice and accountability, government effectiveness, regulatory quality, rule of law, and control of corruption. I use these measures with inverted sign, one at a time, as alternative proxies for political instability, although they are potentially less accurate measures. Nevertheless, there is evidence that worse scores along these governance dimensions are correlated with higher levels of capital taxes and debt.

Table 4: Empirical relation between political stability, capital taxes and debt

\begin{tabular}{|c|c|c|c|c|c|c|c|}
\hline & (1) & $(2)$ & $(3)$ & (4) & $(5)$ & (6) & (7) \\
\hline \multicolumn{8}{|c|}{ (a) Dependent variable: tax rate on capital } \\
\hline Governance $_{t-1} 1-7$ & $\begin{array}{c}0.032^{* * *} \\
(0.004)\end{array}$ & $\begin{array}{c}0.012^{* * *} \\
(0.000)\end{array}$ & $\begin{array}{c}-0.012 \\
(0.250)\end{array}$ & $\begin{array}{c}0.006 \\
(0.622)\end{array}$ & $\begin{array}{c}0.043^{* *} \\
(0.029)\end{array}$ & $\begin{array}{c}0.022 \\
(0.229)\end{array}$ & $\begin{array}{c}0.013 \\
(0.664)\end{array}$ \\
\hline$R^{2}$ & 0.86 & 0.84 & 0.86 & 0.86 & 0.86 & 0.86 & 0.86 \\
\hline $\mathrm{N}$ & 374 & 395 & 374 & 374 & 374 & 374 & 374 \\
\hline \multirow[b]{2}{*}{ Governance $_{t-1} 1-7$} & \multicolumn{7}{|c|}{ (b) Dependent variable: debt/GDP } \\
\hline & $\begin{array}{c}0.054^{* * *} \\
(0.000)\end{array}$ & $\begin{array}{c}0.013^{* * *} \\
(0.006)\end{array}$ & $\begin{array}{c}0.075^{* * *} \\
(0.000)\end{array}$ & $\begin{array}{c}0.058^{* *} \\
(0.018)\end{array}$ & $\begin{array}{c}0.123^{* * *} \\
(0.001)\end{array}$ & $\begin{array}{c}0.191^{* * *} \\
(0.000)\end{array}$ & $\begin{array}{c}0.252^{* * *} \\
(0.000)\end{array}$ \\
\hline$R^{2}$ & 0.81 & 0.82 & 0.81 & 0.81 & 0.81 & 0.82 & 0.82 \\
\hline $\mathrm{N}$ & 627 & 592 & 630 & 628 & 630 & 628 & 632 \\
\hline \multicolumn{8}{|c|}{ Controls included in panel (a) and (b) } \\
\hline$\hat{a}_{t-1}, \hat{z}_{t-1}, \hat{g}_{t-1}$ & yes & yes & yes & yes & yes & yes & yes \\
\hline Year FE & yes & yes & yes & yes & yes & yes & yes \\
\hline Country FE & yes & yes & yes & yes & yes & yes & yes \\
\hline
\end{tabular}

Notes: [1] Governance indicator used in (1)-(7): Political Stability, State Fragility, Voice and Accountability, Government Effectiveness, Regulatory Quality, Rule of Law, Control of Corruption.

[2] P-values based on panel corrected standard errors in parenthesis.

$[3] * * *, * *$, and $*$ indicate significance at the $1 \%, 5 \%$, and $10 \%$ level, respectively. 


\subsection{Main empirical results}

This section contains the main empirical result based on the preferred measure of political instability used in column (1) of Table 4. I correct for a variety of relevant third factors that affect instability and capital taxes, or debt, and show that the relation remains significant. Specifically, I control for structural country characteristics, for an alternative of generating public revenues, and for long-term public financing needs, following Swank and Steinmo (2002). Columns (1) to (7) of Table 5 successively add to the previous specification the size of GDP, total population, the shares of elderly, rural, and urban in total population, respectively, inflation, and the ratio of government consumption to GDP. The relation between political instability and capital taxes and debt is positive and significant at the $1 \%$ level in 13 out of 14 regressions and at the $5 \%$ level in one. Moreover, the point estimates are quantitatively similar within panels and economically relevant. Column (1) suggests that if the politically most unstable country in the sample, Turkey, had the same mean stability level as the most stable country, Finland, and keeping everything else constant, its average capital tax rate would be 8 percentage points lower and its debt ratio 13 percentage points.

Table 5: Main results

\begin{tabular}{|c|c|c|c|c|c|c|c|}
\hline & (1) & $(2)$ & $(3)$ & $(4)$ & $(5)$ & $(6)$ & $(7)$ \\
\hline \multirow[b]{2}{*}{ Pol. instab.t-1 } & \multicolumn{7}{|c|}{ (a) Dependent variable: tax rate on capital } \\
\hline & $\begin{array}{c}0.033^{* * *} \\
(0.004)\end{array}$ & $\begin{array}{c}0.034^{* * *} \\
(0.003)\end{array}$ & $\begin{array}{c}0.033^{* * *} \\
(0.004)\end{array}$ & $\begin{array}{c}0.027^{* * *} \\
(0.009)\end{array}$ & $\begin{array}{c}0.027^{* * *} \\
(0.010)\end{array}$ & $\begin{array}{c}0.026^{* * *} \\
(0.009)\end{array}$ & $\begin{array}{c}0.027^{* * *} \\
(0.010)\end{array}$ \\
\hline$R^{2}$ & 0.86 & 0.86 & 0.86 & 0.86 & 0.86 & 0.86 & 0.86 \\
\hline $\mathrm{N}$ & 374 & 374 & 374 & 374 & 374 & 374 & 374 \\
\hline & \multicolumn{7}{|c|}{ (b) Dependent variable: debt/GDP } \\
\hline Pol. instab.t-1 & $\begin{array}{c}0.052^{* * *} \\
(0.000)\end{array}$ & $\begin{array}{c}0.056^{* * *} \\
(0.000)\end{array}$ & $\begin{array}{c}0.047^{* * *} \\
(0.000)\end{array}$ & $\begin{array}{c}0.037^{* * *} \\
(0.003)\end{array}$ & $\begin{array}{c}0.038^{* * *} \\
(0.003)\end{array}$ & $\begin{array}{c}0.039^{* * *} \\
(0.002)\end{array}$ & $\begin{array}{c}0.034^{* *} \\
(0.019)\end{array}$ \\
\hline$R^{2}$ & 0.81 & 0.82 & 0.83 & 0.84 & 0.84 & 0.84 & 0.84 \\
\hline $\mathrm{N}$ & 627 & 627 & 627 & 627 & 627 & 627 & 627 \\
\hline \multicolumn{8}{|c|}{ Controls included in panel (a) and (b) } \\
\hline$\hat{a}_{t-1}, \hat{z}_{t-1}, \hat{g}_{t-1}$ & yes & yes & yes & yes & yes & yes & yes \\
\hline Year FE & yes & yes & yes & yes & yes & yes & yes \\
\hline Country FE & yes & yes & yes & yes & yes & yes & yes \\
\hline $\mathrm{GDP}_{t-1}$ & yes & yes & yes & yes & yes & yes & yes \\
\hline Popul.t-1 $_{t-1}$ & & yes & yes & yes & yes & yes & yes \\
\hline Elderly $_{t-1}$ & & & yes & yes & yes & yes & yes \\
\hline Rural $_{t-1}$ & & & & yes & yes & yes & yes \\
\hline Urban.t-1 & & & & & yes & yes & yes \\
\hline Inflation $_{t-1}$ & & & & & & yes & yes \\
\hline$(g / y)_{t-1}$ & & & & & & & yes \\
\hline
\end{tabular}

Notes: [1] P-values based on panel corrected standard errors in parenthesis.

$[2] * * *, * *$, and $*$ indicate significance at the $1 \%, 5 \%$, and $10 \%$ level, respectively. 


\subsection{Sensitivity analysis}

To test the sensitivity of the main empirical results, in this section I first use a variety of alternative estimators. Then, I employ a different data set to assess the relation between variables out-of-sample. Table 6 shows the results for the baseline specification but using different estimators. Instead of adding further control variables to correct for other potentially relevant variables, the first column is based on the common correlated effects estimator of Pesaran (2006). It controls for common unobserved factors among countries. Technically, the estimator is implemented by augmenting the observed regressors with cross-sectional averages of the dependent variable and the country-specific regressors. To avoid multicollinearity, the year dummies are dropped. Column (2) and (3) use pooled OLS and fixed-effects estimation, both with robust standard errors. In column (4), contemporaneous political instability is instrumented with its first lag within an fixed-effects estimator as an alternative to using its first lag to address potential problems of reverse causality. The final column uses seemingly unrelated regressions. All models contain two lags of the dependent variable to remove autocorrelation from the error terms. The lag length is based on individual lag significance. Overall, the relation between political instability and the dependent variables remains statistically significant at least at the five percent level in eight of the ten cases. Only for the fixed-effects estimator the significance is around the ten percent level.

Table 6: Alternative estimators

\begin{tabular}{|c|c|c|c|c|c|}
\hline Estimator & $\begin{array}{c}(1) \\
\mathrm{CCE}\end{array}$ & $\begin{array}{c}(2) \\
\text { pooled OLS }\end{array}$ & $\begin{array}{l}(3) \\
\mathrm{FE}\end{array}$ & $\begin{array}{c}(4) \\
\text { FE IV }\end{array}$ & $\begin{array}{c}(5) \\
\text { SURE }\end{array}$ \\
\hline & \multicolumn{5}{|c|}{ (a) Dependent variable: tax rate on capital } \\
\hline Pol. instability ${ }_{t-1}$ & $\begin{array}{c}0.021^{* * *} \\
(0.009)\end{array}$ & $\begin{array}{c}0.022^{* * *} \\
(0.006)\end{array}$ & $\begin{array}{c}0.022 \\
(0.114)\end{array}$ & $\begin{array}{l}0.031^{* *} \\
(0.011)\end{array}$ & $\begin{array}{c}0.021^{* * *} \\
(0.007)\end{array}$ \\
\hline$R^{2}$ & 0.97 & 0.97 & 0.64 & 0.63 & 0.97 \\
\hline $\mathrm{N}$ & 370 & 370 & 370 & 370 & 355 \\
\hline \multicolumn{6}{|c|}{ (b) Dependent variable: debt/GDP } \\
\hline Pol. instability $y_{t-1}$ & $\begin{array}{l}0.021^{* *} \\
(0.024)\end{array}$ & $\begin{array}{l}0.020^{* *} \\
(0.029)\end{array}$ & $\begin{array}{l}0.020^{*} \\
(0.067)\end{array}$ & $\begin{array}{l}0.028^{* *} \\
(0.027)\end{array}$ & $\begin{array}{c}0.030^{* * *} \\
(0.007)\end{array}$ \\
\hline$R^{2}$ & 0.99 & 0.99 & 0.94 & 0.94 & 0.99 \\
\hline $\mathrm{N}$ & 615 & 615 & 615 & 615 & 355 \\
\hline \multicolumn{6}{|c|}{ Controls included in panel (a) and (b) } \\
\hline 2 lags endog. & yes & yes & yes & yes & yes \\
\hline$\hat{a}_{t-1}, \hat{z}_{t-1}, \hat{g}_{t-1}$ & yes & yes & yes & yes & yes \\
\hline Year FE & no & yes & yes & yes & yes \\
\hline Country FE & yes & yes & yes & yes & yes \\
\hline
\end{tabular}

Notes: [1] P-values in parenthesis.

$[2] * * *, * *$, and $*$ indicate significance at the $1 \%, 5 \%, 10 \%$ level. 
Table 7: Out-of-sample analysis (1965-1982)

\begin{tabular}{|c|c|c|c|c|c|c|}
\hline \multirow{3}{*}{$\begin{array}{l}\text { Dep. variable } \\
\text { Estimator }\end{array}$} & \multicolumn{3}{|c|}{ Capital tax rate } & \multicolumn{3}{|c|}{ Debt/GDP } \\
\hline & (1) & $(2)$ & $(3)$ & $(4)$ & $(5)$ & $(6)$ \\
\hline & PCSE & $\mathrm{FE}$ & $\mathrm{FE}$ & PCSE & $\mathrm{FE}$ & $\mathrm{FE}$ \\
\hline Pol. instability & $\begin{array}{c}0.175^{* * *} \\
(0.001)\end{array}$ & $\begin{array}{c}0.235^{* * *} \\
(0.000)\end{array}$ & $\begin{array}{c}0.237^{* * *} \\
(0.000)\end{array}$ & $\begin{array}{l}-0.047 \\
(0.698)\end{array}$ & $\begin{array}{l}0.045^{*} \\
(0.077)\end{array}$ & $\begin{array}{c}0.068^{* *} \\
(0.044)\end{array}$ \\
\hline Dep. variable $_{t-1}$ & & $\begin{array}{c}0.875^{* * *} \\
(0.000)\end{array}$ & $\begin{array}{c}0.929^{* * *} \\
(0.000)\end{array}$ & & $\begin{array}{c}1.194^{* * *} \\
(0.000)\end{array}$ & $\begin{array}{c}1.108^{* * *} \\
(0.000)\end{array}$ \\
\hline Dep. variable $_{t-2}$ & & $\begin{array}{c}-0.418^{* * *} \\
(0.003)\end{array}$ & $\begin{array}{c}-0.544^{* * *} \\
(0.000)\end{array}$ & & $\begin{array}{l}-0.275 \\
(0.168)\end{array}$ & $\begin{array}{c}0.101 \\
(0.510)\end{array}$ \\
\hline Dep. variable ${ }_{t-3}$ & & & $\begin{array}{c}0.150 \\
(0.112)\end{array}$ & & & $\begin{array}{c}-0.320^{* * *} \\
(0.000)\end{array}$ \\
\hline Year FE & yes & yes & yes & yes & yes & yes \\
\hline Country FE & yes & yes & yes & yes & yes & yes \\
\hline$R^{2}$ & 0.79 & 0.74 & 0.72 & 0.66 & 0.93 & 0.92 \\
\hline $\mathrm{N}$ & 230 & 196 & 180 & 205 & 181 & 167 \\
\hline
\end{tabular}

Notes: [1] Panel corrected and robust p-values, respectively, in parenthesis. $[2] * * *, * *$, and $*$ indicate significance at the $1 \%, 5 \%, 10 \%$ level.

Table 7 contains out-of-sample results. They are based on data for the period 19651982 and a subset of 13 countries. The sample is restricted by the joint availability of data on capital taxes, debt, and an alternative measure of political instability. Specifically, I use the index of Gupta (1990) which is only available until 1982. For the given country sample, it basically comprises events such as political strikes, riots, and anti-government demonstrations in the subclass of 'anomic violence' and death, armed attacks, and assassinations in the subclass of 'internal war', with higher values implying greater instability. The index has been used by Venieris and Gupta (1986) and Perotti (1996), among others, to study the effects of political instability on savings or growth. Data on capital taxes for this period are only available from the tables of Mendoza et al. (1994) as the original data underlying the construction of these tax rates are no longer available from OCED sources. Columns (1)-(3) show results for capital taxes as the dependent variable. The first column uses the baseline estimator. Column (2) is based on the fixed-effects estimator which yields, according to Table 6, the most conservative estimate of the statistical significance of the relation between political instability and the dependent variables. As the second lag of the dependent variable is highly significant, the third column adds another lag to the model. In columns (3)-(6), the same three models are estimated with government debt as the dependent variable. All in all, the table suggests a statistically significant relation between political instability and capital taxes or government debt also in the earlier sample. 


\section{Conclusions}

The paper provides a dynamic representative-agent model of optimizing fiscal policy under uncertainty. The government has access to linear taxes on labor and capital and to non-state-contingent bonds. Bond holdings and capital taxes are subject to adjustment costs and markets are incomplete. The main feature of the model is an impatient government which discounts the future at higher rates than households. This implies positive long-run capital taxes and government debt for already modest differences in discount rates. A Bayesian prior predictive analysis shows that the model matches the level and distribution of capital taxes and debt in the data, together with other business cycle statistics. Consistent with these predictions, the paper then presents econometric evidence of a significant positive relation between political instability, used to proxy unobservable public discount rates, and capital taxes and debt.

The paper complements existing studies that rationalize non-zero capital taxation (see Piketty and Saez, 2013, Straub and Werning, 2014). The quantitative macroeconomic model accounts for several stylized facts about fiscal policy that standard models lack to explain. The empirical results contribute to a literature which finds that political instability is associated with short-term oriented macroeconomic policies. In the context of monetary policy, Cukierman et al. (1992) and Aisen and Veiga (2006) show that countries with higher political instability tend to have higher inflation.

\section{References}

AdAm, K. (2011): "Government debt and optimal monetary and fiscal policy," European Economic Review, 55(1), 57 - 74, Special Issue on Monetary and Fiscal Interactions in Times of Economic Stress.

Adam, K., And M. Grill (2013): "Optimal sovereign default," Discussion Paper, Deutsche Bundesbank 09/2013.

Aguiar, M., M. Amador, And G. Gopinath (2009): "Investment cycles and sovereign debt overhang," The Review of economic studies, 76(1), 1-31.

Aisen, A., And F. J. Veiga (2006): "Does Political Instability Lead to Higher Inflation? A Panel Data Analysis.," Journal of Money, Credit and Banking, 38(5), 1379 - 1389.

Aiyagari, S. R., A. Marcet, T. J. Sargent, And J. Seppälä (2002): "Optimal Taxation without State-Contingent Debt," Journal of Political Economy, 110(6), 1220-1254.

Aizenman, J. (1992): "Competitive Externalities and the Optimal Seigniorage," Journal of Money, Credit and Banking, 24(1), 61-71.

Alesina, A., And G. Tabellini (1990): "A Positive Theory of Fiscal Deficits and Government Debt," The Review of Economic Studies, 57(3), 403-414.

Amador, M. (2004): "A political economy model of sovereign debt repayment," mimemo, Stanford University. 
Angeletos, G.-M. (2002): "Fiscal policy with noncontingent debt and the optimal maturity structure," The Quarterly Journal of Economics, 117(3), 1105-1131.

Arrow, K., AND M. Kurz (1970): "Public investment, the rate of return, and optimal fiscal policy," .

Azzimonti-Renzo, M. (2007): "On the dynamic inefficiency of governments," University of Iowa, mimemo.

Battaglini, M., And S. Coate (2008): "A Dynamic Theory of Public Spending, Taxation, and Debt," American Economic Review, 98(1), 201-36.

Beck, N., And J. N. Katz (1995): "What to do (and not to do) with Time-Series Cross-Section Data," The American Political Science Review, 89(3), 634-647.

Beetsma, R., And M. Giuliodori (2011): "The Effects of Government Purchases Shocks: Review and Estimates for the EU*," The Economic Journal, 121(550), F4-F32.

Blanchard, O., and R. Perotti (2002): "An empirical characterization of the dynamic effects of changes in government spending and taxes on output," the Quarterly Journal of economics, 117(4), 1329-1368.

Bonis, V. D., and L. Spataro (2005): "Taxing capital income as Pigouvian correction: The role of discounting future," Macroeconomic Dynamics, 9(04), 469-477.

Borgy, V., T. Laubach, J. Mesonnier, and J. Renne (2011): "Fiscal Sustainability, Default Risk and Euro Area Sovereign Bond Spreads Markets," Working Paper No. 350, Banque de France.

Chamley, C. (1986): "Optimal Taxation of Capital Income in General Equilibrium with Infinite Lives," Econometrica, 54(3), 607-622.

Chari, V., and P. J. Kehoe (1999): "Optimal fiscal and monetary policy," in Handbook of Macroeconomics, ed. by J. B. Taylor, and M. Woodford, Handbook of Macroeconomics, chap. 26, pp. 1671-1745. Elsevier.

Chari, V. V., L. J. Christiano, and P. J. Kehoe (1994): "Optimal Fiscal Policy in a Business Cycle Model," Journal of Political Economy, 102, 617-652.

Chari, V. V., And P. J. Kehoe (1990): "Sustainable plans," Journal of political economy, 98(4), 783-802.

Cukierman, A., S. Edwards, and G. Tabellini (1992): "Seigniorage and Political Instability," American Economic Review, 82(3), 537-55.

Devereux, M. B., And J.-F. Wen (1998): "Political instability, capital taxation, and growth," European Economic Review, 42(9), 1635 - 1651.

Diamond, P., and J. Spinnewijna (2011): "Capital income taxes with heterogeneous discount rates," American Economic Journal: Economic Policy, 3(4), 52-76.

Engen, E. M., and R. G. Hubbard (2004): "Federal Government Debt and Interest Rates," NBER Working Papers 10681, National Bureau of Economic Research, Inc.

FARHI, E. (2010): "Capital Taxation and Ownership When Markets Are Incomplete," Journal of Political Economy, 118(5), 908 - 948.

Faust, J., AND A. Gupta (2012): "Posterior predictive analysis for evaluating DSGE models," Discussion paper, National Bureau of Economic Research.

Gale, W. G., And P. R. Orszag (2003): "Economic Effects of Sustained Budget Deficits.," National Tax Journal, 56(3), $463-485$. 
García-Cicco, J., R. Pancrazi, And M. Uribe (2010): "Real Business Cycles in Emerging Countries?," American Economic Review, 100, 2510-2531.

Grossman, H. I., And J. B. Van Huyck (1988): "Sovereign Debt as a Contingent Claim: Excusable Default, Repudiation, and Reputation.," American Economic Review, 78(5), 1088.

Gupta, D. K. (1990): The Economics of Political Violence: Effect of Political Instability on Economic Growth. Praeger.

Heaton, J., AND D. J. LuCAS (1996): "Evaluating the effects of incomplete markets on risk sharing..." Journal of Political Economy, 104(3), 443.

Hiraguchi, R., And A. Shibata (2015): "Taxing capital is a good idea: The role of idiosyncratic risk in an OLG model," Journal of Economic Dynamics and Control, 52, 258 269.

JUDD, K. L. (1985): "Redistributive taxation in a simple perfect foresight model," Journal of Public Economics, 28(1), 59 - 83.

King, R. G., And S. T. Rebelo (1999): "Resuscitating real business cycles," Handbook of macroeconomics, 1, 927-1007.

Kumar, M. S., And E. Baldacci (2010): "Fiscal Deficits, Public Debt, and Sovereign Bond Yields," IMF Working Paper No. 10/184.

Kumhof, M., And I. Yakadina (2007): "Politically Optimal Fiscal Policy," IMF Working Papers 07/68, International Monetary Fund.

LANSING, K. (1999): "Optimal redistributive capital taxation in a neoclassical growth model," Journal of Public Economics, 73.

Laubach, T. (2009): "New Evidence on the Interest Rate Effects of Budget Deficits and Debt," Journal of the European Economic Association, 7(4), 858-885.

Lubik, T., And F. Schorfheide (2005): "A Bayesian Look at New Open Economy Macroeconomics," NBER Macroeconomics Annual, 20, 313-366.

Marcet, A., And A. Scott (2009): "Debt and deficit fluctuations and the structure of bond markets," Journal of Economic Theory, 144(2), 473 - 501.

Martin, F. M. (2010): "Markov-perfect capital and labor taxes," Journal of Economic Dynamics and Control, 34(3), $503-521$.

Mendoza, E. G., A. Razin, And L. L. Tesar (1994): "Effective tax rates in macroeconomics: Cross-country estimates of tax rates on factor incomes and consumption," Journal of Monetary Economics, 34(3), 297 - 323.

Neumeyer, P. A., And F. Perri (2005): "Business cycles in emerging economies: the role of interest rates," Journal of Monetary Economics, 52(2), 345 - 380.

Nunes, R., And D. Debortoli (2011): "Political Disagreement, Lack of Commitment and the Level of Debt," Discussion paper.

OECD (2014): "OECD Economic Outlook, Volume 2014 Issue 2," .

Perotti, R. (1996): "Growth, Income Distribution, and Democracy: What the Data Say," Journal of Economic Growth, 1(2), 149-87.

Persson, M., T. Persson, And L. E. Svensson (2006): "Time consistency of fiscal and monetary policy: a solution," Econometrica, 74(1), 193-212. 
Persson, T., and L. E. O. Svensson (1989): "Why a Stubborn Conservative Would Run a Deficit: Policy with Time-Inconsistent Preferences," The Quarterly Journal of Economics, 104(2), 325-45.

Pesaran, M. H. (2006): "Estimation and inference in large heterogeneous panels with a multifactor error structure," Econometrica, 74(4), 967-1012.

Piketty, T., ANd E. Saez (2013): "A theory of optimal inheritance taxation," Econometrica, $81(5), 1851-1886$.

REIS, C. (2012): "Social discounting and incentive compatible fiscal policy," Journal of Economic Theory, 147(6), 2469-2482.

Schmitt-Grohé, S., And M. Uribe (2003): "Closing small open economy models," Journal of International Economics, 61(1), 163 - 185.

Straub, L., And I. Werning (2014): "Positive Long Run Capital Taxation: Chamley-Judd Revisited," Discussion paper, National Bureau of Economic Research.

Swank, D., And S. Steinmo (2002): "The New Political Economy of Taxation in Advanced Capitalist Democracies.," American Journal of Political Science, 46(3), 642.

Trabandt, M., And H. Uhlig (2011): "The Laffer curve revisited," Journal of Monetary Economics, 58(4), 305-327.

Venieris, Y. P., And D. K. Gupta (1986): "Income Distribution and Sociopolitical Instability as Determinants of Savings: A Cross-section Model.," Journal of Political Economy, 94(4), $873-883$.

von Hagen, J., And I. J. Harden (1995): "Budget processes and commitment to fiscal discipline," European Economic Review, 39(3), 771 - 779, Papers and Proceedings of the Ninth Annual Congress European Economic Association.

Wyplosz, C. (2005): "Fiscal Policy: Institutions versus Rules," National Institute Economic Review, 191(1), 64-78.

\section{A Derivations and proofs}

\section{A.1 Derivation of the implementability constraint}

This appendix derives the sequence of implementability constraints (13). Substituting for $R_{t}$ and $\left(1-\tau_{t}^{n}\right) w_{t}$ in (2) by using (4) and (5) and applying $\theta_{t}=\xi_{t}$ yields

$$
b_{t}+R_{t}^{k} k_{t}=c_{t}-\nu n_{t}^{1+\varphi} c_{t}^{\sigma}+z_{t} b_{t+1}\left[z_{t}^{-1} \beta E_{t}\left(\frac{c_{t}}{c_{t+1}}\right)^{\sigma}-\tilde{\theta} b_{t+1}\right]+z_{t} k_{t+1},
$$

with $R_{t}^{k}=\left[1+\left(1-\tau_{t}^{k}\right) F_{k}\left(k_{t}, n_{t}, a_{t}, Z_{t}\right)\right]$. Using that $b_{t}$ in (14) is non-state-contingent and thus known in period $t$ and defining $v_{t} \equiv c_{t}-\nu n_{t}^{1+\varphi} c_{t}^{\sigma}-z_{t} \tilde{\theta} b_{t+1}^{2}$, (14) can be iterated forward $j$ times by replacing $b_{t+1}$ and by using (6). This gives

$$
\begin{aligned}
b_{t}+R_{t}^{k} k_{t}= & v_{t}+\beta E_{t}\left(\left(\frac{c_{t}}{c_{t+1}}\right)^{\sigma} v_{t+1}\right)+\ldots \\
& +\beta^{j} E_{t}\left(\left(\frac{c_{t}}{c_{t+j}}\right)^{\sigma} z_{t+j} k_{t+j}\right)+\beta^{j+1} E_{t}\left(\left(\frac{c_{t}}{c_{t+j+1}}\right)^{\sigma} b_{t+j+1}\right) .
\end{aligned}
$$


Let $j \rightarrow \infty$ and divide both sides by $c_{t}^{\sigma}$

$c_{t}^{-\sigma}\left(b_{t}+R_{t}^{k} k_{t}\right)=E_{t} \sum_{j=0}^{\infty} \beta^{j}\left(c_{t+j}^{-\sigma} v_{t+j}\right)+\lim _{j \rightarrow \infty} \beta^{j} E_{t}\left(c_{t+j}^{-\sigma} z_{t+j} k_{t+j}\right)+\lim _{j \rightarrow \infty} \beta^{j+1} E_{t}\left(c_{t+j+1}^{-\sigma} b_{t+j+1}\right)$.

Finally, using (8) and replacing $v_{t+j}$ and $R_{t}^{k}$ yields (13).

\section{A.2 First order conditions to policy problem}

This appendix contains the first order conditions to the policy problem. The derivations of the Lagrangian with respect to $c_{t}, n_{t}, k_{t+1}, \tau_{t+1}^{k}$, and $b_{t+1}$ for $t \geq 1$ are

$$
\begin{aligned}
0= & -\frac{\chi_{t-1} \sigma R_{t}^{k}}{\gamma \beta z_{t-1} c_{t}^{\sigma+1}}+\frac{1}{c_{t}^{\sigma}}-\eta_{t}+\mu_{t}\left[(1-\sigma) c_{t}^{-\sigma}+\frac{\sigma z_{t} \tilde{\theta} b_{t+1}^{2}}{c_{t}^{\sigma+1}}\right] \\
& +\frac{\psi_{t} \sigma\left(b_{t}+R_{t}^{k} k_{t}\right)}{c_{t}^{\sigma+1}}+\frac{\chi_{t} \sigma}{\beta c_{t}^{\sigma+1}} \\
0= & \frac{\chi_{t-1}}{\gamma \beta z_{t-1} c_{t}^{\sigma}}\left(1-\tau_{t}^{k}\right) F_{k n}\left(k_{t}, n_{t}, a_{t}, Z_{t}\right)-\nu n_{t}^{\varphi}+\eta_{t} F_{n}\left(k_{t}, n_{t}, a_{t}, Z_{t}\right) \\
& -\mu_{t}(1+\varphi) \nu n_{t}^{\varphi}-\frac{\psi_{t}}{c_{t}^{\sigma}}\left(1-\tau_{t}^{k}\right) F_{k n}\left(k_{t}, n_{t}, a_{t}, Z_{t}\right) k_{t} \\
0 & -\eta_{t} z_{t}+\chi_{t} E_{t}\left[z_{t} c_{t+1}^{-\sigma}\left(1-\tau_{t+1}^{k}\right) F_{k k}\left(k_{t+1}, n_{t+1}, a_{t+1}, Z_{t+1}\right)\right] \\
& +\gamma \beta E_{t}\left[-\frac{\psi_{t+1}}{c_{t+1}^{\sigma}}\left(1+\left(1-\tau_{t+1}^{k}\right)\left\{\begin{array}{c}
F_{k k}\left(k_{t+1}, n_{t+1}, a_{t+1}, Z_{t+1}\right) k_{t+1} \\
+F_{k k}\left(k_{t+1}, n_{t+1}, a_{t+1}, Z_{t+1}\right)
\end{array}\right\}\right)\right] \\
0 & -\frac{\chi_{t-1}}{\gamma \beta z_{t-1} c_{t}^{\sigma}} F_{k}\left(k_{t}, n_{t}, a_{t}, Z_{t}\right)-\eta_{t} \kappa\left(\tau_{t}^{k}-\tau^{k}\right) \\
& +\frac{\psi_{t}}{c_{t}^{\sigma}} F_{k}\left(k_{t}, n_{t}, a_{t}, Z_{t}\right) k_{t} \\
0 & -\frac{\mu_{t} 2 z_{t} \tilde{\theta} b_{t+1}}{c_{t}^{\sigma}}-\gamma \beta E_{t}\left[\frac{\psi_{t+1}}{c_{t+1}^{\sigma}}\right],
\end{aligned}
$$

where $R_{t}^{k}=\left[1+\left(1-\tau_{t}^{k}\right) F_{k}\left(k_{t}, n_{t}, a_{t}, Z_{t}\right)\right]$.

\section{A.3 Proof of the proposition and corollary}

Proof of the proposition

(a) Using $\psi=(1-1 / \gamma) \mu,(19)$ in steady state reads $b=(1-\gamma) \beta /(2 \tilde{\theta})$. Hence, for $\gamma<1$ and $\tilde{\theta}>0, b>0$.

(b) With $\sigma=0$, (15), (16), and (18) in steady state read

$$
\begin{aligned}
1+\mu & =\eta \\
\eta & =\chi\left(1-\tau^{k}\right) F_{k k}+\gamma \beta\left\{\eta\left(1+F_{k}\right)-\psi\left[1+\left(1-\tau^{k}\right)\left(F_{k k} k+F_{k}\right)\right]\right\} \\
\chi & =\gamma \beta \psi k .
\end{aligned}
$$

Using (22) to replace $\chi$ in (21) gives $\eta+\psi \gamma \beta\left(1+\left(1-\tau^{k}\right) F_{k}\right)=\gamma \beta \eta\left(1+F_{k}\right)$. Using (6) in steady state, which reads $1=\beta\left(1+\left(1-\tau^{k}\right) F_{k}\right)$, yields $\eta+\psi \gamma=\gamma \beta \eta\left(1+F_{k}\right)$. Substituting for $\eta$ and $\psi$ by using (20) and $\mu=\mu / \gamma+\psi$, respectively, gives $\frac{1+\gamma \mu}{\gamma+\gamma \mu}=$ $\beta\left(1+F_{k}\right)>1$ for $\gamma<1$ since the Lagrange multiplier on the implementability constraint 
$\mu$ is positive in the absence of lump-sum taxes and for $b \geq 0$. Combining this inequality with (6) in steady state shows that $\tau^{k}>0$ if $\gamma<1$.

Proof of corollary

(a) The proof is trivial. It immediately follows from the steady state solution for $b$, which reads $b=(1-\gamma) \beta /(2 \tilde{\theta})$, such that $\partial b / \partial \gamma=-\beta /(2 \tilde{\theta})<0$.

(b) Combining $\frac{1+\gamma \mu}{\gamma+\gamma \mu}=\beta\left(1+F_{k}\right)$ from part (a) of the proposition with (6) in steady state gives $\frac{1+\gamma \mu}{\gamma+\gamma \mu}=1+\beta \tau^{k} F_{k}$. The total derivative with respect to $\gamma$ of this expression evaluated at $\gamma=1$ is $\partial \tau^{k} /\left.\partial \gamma\right|_{\gamma=1}=-\left[(1+\mu) \beta F_{k}\right]^{-1}<0$.

\section{B List of countries, data, and sources}

The countries are: Australia, Austria, Belgium, Bulgaria, Canada, Croatia, Cyprus, Czech Republic, Denmark, Estonia, Finland, France, Germany, Greece, Hungary, Iceland, Ireland, Italy, Japan, Korea, Latvia, Lithuania, Luxembourg, Macedonia, Malta, Mexico, Montenegro, Netherlands, New Zealand, Norway, Poland, Portugal, Romania, Serbia, Slovakia, Slovenia, Spain, Sweden, Switzerland, Turkey, United Kingdom, United States. The coverage is 1985-2014 and the frequency is yearly.

\begin{tabular}{|c|c|}
\hline Variable & Description and source \\
\hline Capital tax rate & $\begin{array}{l}\text { Average effective capital tax rate capital income, constructed as in Mendoza et al. (1994), } \\
23 \text { countries } 1985-2014 \text {, OECD Rev. Statistics; collected from Mendoza et al. (1994) for 1965-1983 }\end{array}$ \\
\hline Labor tax rate & $\begin{array}{l}\text { Average effective capital tax rate on labor income, constructed as in Mendoza et al. (1994), } \\
23 \text { countries, OECD Revenue Statistics }\end{array}$ \\
\hline Government debt & General government consolidated gross debt (UDGGL), AMECO, 37 countries; OECD for 1965-1983 \\
\hline Interest rate & Yield on government debt with maturity one year, Datastream \\
\hline Gov. expend. & Final cons. (and investment) expenditure general gov.current prices (UCTG), AMECO, all countries \\
\hline Output & Gross domestic product at current market prices (UVGD), AMECO, all countries \\
\hline GDP deflator & Price deflator gross domestic product at market prices (PVGD), AMECO, all countries \\
\hline Consumption & Private final consumption expenditure at current prices ( $\mathrm{UCPH}), \mathrm{AMECO}$, all countries \\
\hline Population & Total population (National accounts) (NPTD), AMECO, all countries \\
\hline Govern. Indicators & $\begin{array}{l}\text { Voice and Accountability, Political Stability, Gov. Effectiveness, Regulatory Quality, } \\
\text { Rule of Law, Control Corruption, Worldwide Governance Indicators, World Bank, sample 1996-2014 }\end{array}$ \\
\hline Fragility & State Fragility Index, Center for Systemic Peace, sample 1995-2014 \\
\hline Size & Country size in squared $\mathrm{km}$, World Bank \\
\hline Rural & Rural population ( $\%$ of total), World Bank \\
\hline Real GDP & Real GDP in PPP, World Bank \\
\hline Elderly & Old dependency ratio ( $>64, \%$ working population), World Bank \\
\hline Urban & Urban population ( $\%$ of total), World Bank \\
\hline
\end{tabular}




\section{Impulse responses to technology shocks}

This appendix shows the impulse responses of selected variables to transitory and permanent technology shocks.
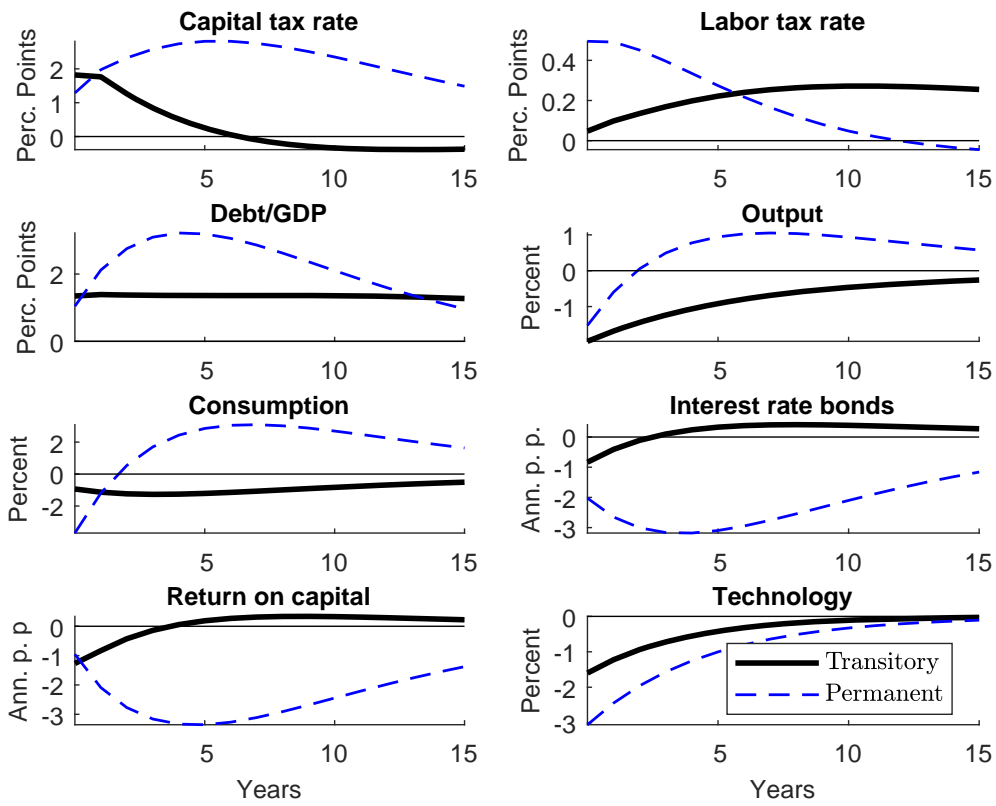

Figure 7: Impulse responses to technology shocks of one standard deviation. Notes: The figure shows the impulse responses of selected variables to transitory (solid line) and permanent (dashed line) technology shocks for the baseline calibration . 